\title{
Avocado fruit quality management during the postharvest supply chain
}

\section{MALICK BILL ${ }^{1,2}$ DHARINI SIVAKUMAR ${ }^{2}$ A KEITH THOMPSON ${ }^{3}$ AND LISE KORSTEN $^{1}$}

1 Department of Microbiology and Plant Pathology, University of Pretoria, Private Bag X20, Hillcrest, South Africa

${ }^{2}$ Department of Crop Science, Tshwane University of Technology, Pretoria West Campus, Private Bag X680, Pretoria West, 0001, South Africa

${ }^{3}$ Hamelmalo Agricultural College, Keren, Eritrea, formally Cranfield University, MK430AL, UK

Avocados are a popular subtropical fruit of high economic importance and the European Union is the biggest importer of the bulk of the fruit coming from countries like South Africa, Chile and Israel. The fruit is highly nutritious being rich in vitamins $A, B, C$, minerals, potassium, phosphorus, magnesium, iron and antioxidants. The biggest challenge is that the fruit is highly susceptible to qualitative and quantitative postharvest losses. Successful maintenance of avocado fruit quality during the supply chain depends on many aspects including adequate orchard management practices, harvesting practices, packing operations, postharvest treatments, temperature management, transportation and storage conditions, and ripening at destination. Postharvest losses are mostly attributed to flesh softening, decay, physiological disorders and improper temperature management. Management of the supply chain is solely done to provide the fruit with the most favourable conditions to extend storage life, retain quality and nutritional attributes of the fruit. The focus of this review is therefore to study the findings that have 
emanated from research done to retain overall avocado fruit quality and to reduce postharvest losses during the supply chain through the adoption of appropriate and novel postharvest technologies.

Keywords Persea Americana, Fruit softening, Postharvest diseases, Packaging, Atmosphere modification

Address correspondence to D. Sivakumar, Department of Crop Sciences, Tshwane University of Technology, Pretoria West Campus, South Africa E-mail dharinisivakumar@yahoo.co.uk; SivakumarD@tut.ac.za; Lise Korsten, Department of Microbiology and Plant Pathology, University of Pretoria E-mail Lise korsten @up.ac.za; Keith Thompson keiththompson28@yahoo.com.

\section{Introduction}

\section{Avocado origin, races and cultivars}

Avocado (Persea americana Mill.), belongs to the family Lauraceae. It is synonymous with $P$. gratissima Gaertn. There are three races: Mexican, Guatemalen and West Indian and some authorities considered the Mexican race a separate species . drymifolia Cham. \& Schlecht. or a separate variety P. americana var. drymifolia Mex. Morton ${ }^{(1)}$ gave the following classification: West Indian as $P$. americana Mill. var. americana ( $P$ gratissima Gaertn.), Mexican as $P$. americana Mill. var. drymifolia Blake ( $P$. drymifolia Schlecht. \& Cham.) and Guatemalan as $P$. nubigena var. guatemalensis $\mathrm{L}$. Wms. The West Indian race is a native of the Central American lowlands and is essentially tropical and produces large fruit with low oil content of only 3 to 
$10 \%$. The Guatemalan is native to the Guatemalan highland and has medium round fruit with an oil content of 8 to $15 \%$ and a leathery, pliable and non-granular ski $n$. The tree is less cold tolerant than the Mexican. The Mexican race thrives best in the subtropics and has the smallest fruit of the three races, with a thin skin and the highest oil of up to $30 \% .{ }^{(2)}$ The tree is most tolerant of cold growing conditions. Chen et al. ${ }^{(3)}$ confirmed that the substantial genetic differentiation among the three ecological races corresponded to the defined horticultural races, but they also reported that the previously undetected genetic differentiation has two subpopulations from Central Mexico. Many cultivars are hybrids between the races. 'Hass' (a Guatemalan x Mexican hybrid) is considered to be the most dominantly grown cultivar in the subtropics $^{(4)}$ and is recognised as the best overall quality avocado available. The fruit weighs between 140 to $400 \mathrm{~g}$ with medium to thick skin, leathery, coarse corky in texture and it turns purplish black when ripe. Other popular cultivars include 'Fuerte' (a Mexican x Guatemalan hybrid), 'Bacon' (a Mexican x Guatemalan hybrid), Pinkerton (a Guatemala hybrid), 'Edranol' (a Guatemala hybrid), 'Ryan' (a Mexican x Guatemalan hybrid', 'Ettinger' (predominantly Mexican) and 'Fuchs' (West Indian). ${ }^{(4)}$ The fruit characteristics of the above mentioned cultivars are shown in Table 1.

\section{Physical properties of avocado}

The fruit (berry) is pear-shaped, oval or round with a short neck. Fruit length can vary from 7.7 $\mathrm{cm}$ to $33 \mathrm{~cm}$ and its width can be up to $15 \mathrm{~cm}$. The skin color of the fruit can vary from yellowish green, dark green or reddish-purple, to dark purple (almost black). The edible portion of the fruit, that is, its flesh or pulp can be pale to bright yellow in color and the fruit flavor is described as a buttery or nut-like flavor. Its single seed is situated at the center of the fruit and 
Table 1

Fruit characteristics of different avocado cultivars ${ }^{\mathrm{a}}$

\begin{tabular}{|c|c|c|c|c|}
\hline Cultivar & Fruit shape & Skin color & Flesh color & Fruit weight \\
\hline Hass & Ovate & Purplish black & Creamy yellow & 140 to $400 \mathrm{~g}$ \\
\hline Fuerte & Pyriform & Green & Pale yellow & 170 to $500 \mathrm{~g}$ \\
\hline Edranol & Pyriform & Dark green & Buttery yellow & 255 to $500 \mathrm{~g}$ \\
\hline Ryan & Pyriform & Green & Golden yellow & 225 to 420 \\
\hline Pinkerton & $\begin{array}{l}\text { Prominantly } \\
\text { pebbled }\end{array}$ & Dark green & Cream-colored & 230 to $425 \mathrm{~g}$ \\
\hline Ettinger & Pyriform & Bright green & $\begin{array}{l}\text { Light cream to } \\
\text { yellow }\end{array}$ & 170 to $570 \mathrm{~g}$ \\
\hline Bacon & Ovate & Green & $\begin{array}{l}\text { Very pale yellow to } \\
\text { green }\end{array}$ & 170 to $510 \mathrm{~g}$ \\
\hline
\end{tabular}

${ }^{\mathrm{a}}$ Source: Whiley et al. ${ }^{(4)}$

the shape of the seed can be oval, round or oblong and generally the length of the seed is around 5 to $6.5 \mathrm{~cm}$ long, but may be smaller. The seed is covered by a thin brown seed coat that adheres to the seed cavity. ${ }^{(4)}$

\section{Avocado production and trade}

Avocados originated in Mexico and Latin America. They have been cultivated in a varying range of habitats including tropical and subtropical regions. ${ }^{(5)}$ Avocados are commercially produced in 
Mexico, Chile, Israel, Spain, South Africa, Peru, Kenya, USA and the Dominican Republic among others. ${ }^{(6)}$ At present, Mexico is the leading producer of avocados in the world followed by Chile and the United States. ${ }^{(4)}$ The majority of avocados produced in Mexico are used domestically as they are a staple food in most Mexican households. ${ }^{(7)}$ In 2011 , avocado production in Mexico was reported to be $337977 \mathrm{t}$ which was approximately $47 \%$ of the world's total quantity. ${ }^{(4)}$ According to the $\mathrm{FAO}^{(8)}$ reports, $13 \%$ of the avocados produced in Mexico are traded internationally. In Chile, South Africa, Israel and Spain, the avocado production is mainly aimed at exporting the fruit to the overseas markets. The world avocado trade is focused on two major markets, namely the European Union (EU), which imports 150,000 to 160,000 t per year including imports from Spain, and the United States, which imports 140,000 t per year. The United Kingdom is the third largest importer of avocados in the EU and it is reported to have imported 11,753 t from South Africa in 2008. ${ }^{(9)}$ Canada and Japan imported about 30,000 $\mathrm{t}$ and 15,000 $\mathrm{t}$ respectively and the Asian, Middle East and Eastern European markets imported less than 20,000 t per year. ${ }^{(10)}$ Peru, South Africa and Israel are the major avocado exporters to the European markets. In the EU, the Netherlands and France as well as the UK are the major avocado importing countries. Although the 'Fuerte' cultivar displays a green skin color after ripening and is well known in the European markets, the 'Hass' cultivar currently dominates the international trade market due to its longer shelf life, large fruit size and its higher consumer acceptance due to its rich nut-like flavor. ${ }^{(11,12)}$ 'Hass' is the dominant and most popular type grown in the USA for export. The avocado export markets are segmented according to cultivars. Hass differs significantly from other cultivars including Fuerte, Etinger and Pinkerton, which have a green skin. 


\section{Fruit nutritional composition and aroma volatiles}

Avocado is nutrient rich fruit with the composition depending on ecotype, cultivar, degree of maturity, and growing conditions. ${ }^{(13)}$ The mesocarp consists of parenchymatous cells with idioblasts containing oil ${ }^{(14)}$ and when ripe the flesh is greenish yellow to bright yellow and buttery in consistency, but inferior varieties may be fibrous. Carotenoids (70\% lutin) and chlorophyll are responsible for the greenish yellow to bright yellow color of the mesocarp. ${ }^{(15)}$ Carotenoids, including lutein $\left(2.93 \mu \mathrm{g} \mathrm{g}^{-1}\right)$, zeaxanthin $\left(0.11 \mu \mathrm{g} \mathrm{g}^{-1}\right), \alpha$-cryptoxanthin $\left(0.25 \mu \mathrm{g} \mathrm{g}^{-}\right.$ $\left.{ }^{1}\right), \beta$-carotene $\left(0.60 \mu \mathrm{g} \mathrm{g}^{-1}\right)$ and $\alpha$-carotene $\left(0.25 \mu \mathrm{g} \mathrm{g}^{-1}\right)$ are reported in the mesocarp of ripened Hass. ${ }^{(16)}$ The ripe fruit contains vitamin A, B, C, minerals, potassium, phosphorus, magnesium and iron. The fruit also contains high levels of lipophilic, bioactive phytochemicals including vitamin E, carotenoids and sterols that display antioxidant and radical scavenging activities. ${ }^{(17)}$

Table 2

Chemical compositions of avocado fruit (per 100g of edible portion) ${ }^{\mathrm{a}}$

\begin{tabular}{llll}
\hline \multicolumn{3}{l}{ Chemical compositions of avocado fruit } & \\
\hline Energy value (Cal) & 245.00 & $\mathrm{~K}(\mathrm{mg})$ & 368.00 \\
Protein $(\mathrm{g})$ & 1.70 & $\mathrm{P}(\mathrm{mg})$ & 38.00 \\
Fat $(\mathrm{g})$ & 26.40 & $\mathrm{Mg}(\mathrm{mg})$ & 35.00 \\
Total carbonhydrate (g) & 5.10 & $\mathrm{~S}(\mathrm{mg})$ & 28.50 \\
Crude fibre (g) & 1.80 & Sulphur & 11.00 \\
$\beta$-caratone & 0.17 & $\mathrm{Chlorine}(\mathrm{mg})$ & 10.00 \\
Ascorbic acid (mg) & 16.00 & $\mathrm{Ca}(\mathrm{mg})$ & 4.21 \\
Niacin (mg) & 1.01 & $\mathrm{Mn}(\mathrm{mg})$ & 3.00 \\
Riboflavin (mg) & 0.13 & $\mathrm{Na} \mathrm{(mg)}$ & 0.60 \\
Thiamine (mg) & 0.06 & $\mathrm{Fe}(\mathrm{mg})$ & 0.45 \\
\hline${ }^{\mathrm{a}}$ Source: FAO ${ }^{(18)}$ & &
\end{tabular}


The chemical composition of the edible portion of the fruit is presented in Table 2 . The edible portion of the fruit is high in lipid, which varies from $3 \%$ to $30 \%$ of its fresh weight and it is also rich in oleic, palmitic, linoleic, and palmitoleic acids, as well as stearic acid in trace amounts. ${ }^{(19)}$ The fatty acid composition in avocado mesocarp is as follows: oleic acid ( $86 \mathrm{mg} \mathrm{g}^{-1}$ oil), palmitic acid (32 $\mathrm{mg} \mathrm{g}^{-1}$ oil), linolenic acid (19 $\mathrm{mg} \mathrm{g}^{-1}$ oil) and palmitoleic acid (14 $\mathrm{mg} \mathrm{g}^{-1}$ oil). ${ }^{(19)}$ Ozdemir and Topuz ${ }^{(20)}$ indicated that in 'Fuerte' oleic acid is the only fatty acid that increased continuously during the season and during ripening at $20{ }^{\circ} \mathrm{C}$ for 1 week with percentages ranging from 65.5 to $71.21 \%$ while palmitic acid decreased from 18.5 to $16.0 \%$ during maturation on the tree and from 16.0 to $14.5 \%$ during ripening at $20{ }^{\circ} \mathrm{C}$ for 1 week. Similarly, linolenic acid showed a regular decrease as the season progressed from 4.54 to $2 \%$ and from 3.0 to $1.4 \%$ in ripening at $20{ }^{\circ} \mathrm{C}$ for 1 week. The phenolic content of fruits was also shown to be affected by the degree of maturity. The phenolics found were $p$-hydroxybenzoic, protocatechuic, Bresorcyclic, $\gamma$ resorcyclic, $\alpha$-resorcyclic, gallic, isovanillic, vanillic, syringic, $o$-coumaric, $m$-coumaric, $p$ coumaric, caffeic, ferulic, and sinapic acids. ${ }^{(21)}$ Work by Golukcu1 and Feramuz Ozdemir ${ }^{(22)}$ on 'Bacon', 'Zutano', 'Fuerte', and 'Hass' indicated that protocatechuic acid, caffeic acid, (-)epicatechin, and rutin were the main phenolic compounds. Although differences were noted in the phenolic composition of the fruit the general trend was that $o$-coumaric acid and rutin contents increased from the first to the second harvesting period (between January and February) and decreased from the second to the third harvesting period (between February and March). In contrast, the quercetin content of all of the cultivars increased steadily during the harvesting period. They concluded that the total phenolic content of avocados increases at the beginning of 
the harvesting period up to the second harvesting time, and it decreases at the end of the harvesting time.

Ethanol, (Z)-3-hexanol and (E)-2-hexenal were reported as the abundant volatiles in whole green and ripe 'Fuerte' avocados by El-Mageed. ${ }^{(23)}$ Sesquiterpenes and hexanal were reported as the most abundant volatiles in the headspace of unripe, diced 'Simmonds' avocado; however, the concentrations of these compounds were noted to decrease during ripening. ${ }^{(24)}$ Obenland et al. (25) reported 25 aroma volatiles, including aldehydes, alcohols, esters, ketones and terpenes and 12 of these aroma volatiles were noted to change in concentration during maturation in 'Hass' avocado from California USA. Of these, 1-penten-3-one, hexanal, (E)-2-hexenal, 2,4-hexadienal, benzaldehyde deceased while acetaldehyde, methyl acetate, pentanal, $\beta$-myrcene, 2,4-heptadienal and nonanal increased as the season progressed (increasing harvest dates). 1-penten- 3-ol and 1penten-3-one were reported to increase during ripening in avocado. ${ }^{(26) .}$ El-Mageed ${ }^{(23)}$ also reported a decline in hexanal (grassy note) in avocados during ripening.

\section{Fruit respiration and ethylene production}

Avocado is classified as a climacteric fruit and it is extremely unusual since the fruit does not ripen while on the tree. Avocado fruit produces higher concentrations of ethylene $\left(80-100 \mu \mathrm{L} \mathrm{L}^{-}\right.$ $\left.{ }^{1}\right)$ in comparison to other climacteric fruits such as mangoes $\left(3 \mu \mathrm{L} \mathrm{L}^{-1}\right)$ and bananas $\left(40 \mu \mathrm{L} \mathrm{L}^{-1}\right)$. (27) Mature fruit displays a characteristic respiratory pattern that coincides with increased ethylene production. This increase in respiration rate and ethylene biosynthesis is accompanied by a complex of biochemical changes including an increased cellulose activity resulting in fruit softening, ${ }^{(28)}$ flesh color changes and synthesis of flavor and aroma chemicals. ${ }^{(29)}$ The increase in the $\mathrm{CO}_{2}$ and ethylene $\left(\mathrm{C}_{2} \mathrm{H}_{4}\right)$ production rate coincides with ripening, resulting in the amino acid 
methionine being converted to S-adenosyl methionine, the precursor of 1-aminocyclopropane-1carboxylic acid, which is the immediate precursor of $\mathrm{C}_{2} \mathrm{H}_{4}$. The 1-aminocyclopropane-1carboxylic acid synthase converts S-adenosyl methionine to 1-aminocyclopropane-1-carboxylic acid and 1-minocyclopropane-1-carboxylic acid oxidase; that is, the ethylene-forming enzyme that is membrane bound, participates in the conversion of 1-aminocyclopropane-1-carboxylic acid to $\mathrm{C}_{2} \mathrm{H}_{4}$. The function of 1-aminocyclopropane-1-carboxylic acid synthase and aminocyclopropane-1-carboxylic acid oxidase is influenced by storage temperatures and gas compositions surrounding the fruit. ${ }^{(30)}$ The temperature during the ripening phase is important with temperatures above $30{ }^{\circ} \mathrm{C}$ causing adverse effects on avocados during ripening. ${ }^{(31,32)}$ Temperatures between $20{ }^{\circ} \mathrm{C}$ and $25{ }^{\circ} \mathrm{C}$ are favorable to ripening avocado cultivars. During ripening, a loss of firmness (texture) takes place due to rapid changes that occur in the ultrastructure of the cell wall and its components. ${ }^{(14)}$ These cell wall structural changes are due to the activities of degrading cellulase enzymes in the cell wall ${ }^{(28,33)}$ and polygalacturonase that result in decreased tissue cohesiveness resulting from the degradation of pectin and cell disarrangement. ${ }^{(34)}$ The mesocarp of an avocado contains common heptoses (C7) sugar, mannoheptulose ${ }^{(35)}$ and its corresponding sugar alcohol, perseitol. ${ }^{(36)}$ A decrease in the C7 sugar content of avocados during ripening has been reported by Bertling and Bower ${ }^{(37)}$, Liu et al. ${ }^{(38)}$ and Meyer and Terry. ${ }^{(39)}$ However, despite C7 carbohydrates playing a major role in the carbon balance, sucrose has not been considered as an indicator to determine postharvest quality. ${ }^{(37,38)}$ Nonetheless, C7 sugars were reported to decrease with fruit maturity. ${ }^{(37)}$ It was suggested that the differences in sugar content between the cultivars and growing regions could affect the postharvest fruit quality. ${ }^{(40)}$ 


\section{Maturity indices for harvesting avocados}

Maturity indices for harvesting avocados are important in order to prevent harvesting of immature or over mature fruit and to reduce postharvest losses. Harvesting immature fruit can result in inadequate ripening, resulting in an inferior fruit quality. Blakey et al. ${ }^{(41)}$ commented that "avocado fruit are highly variable, and even those graded for similar size and appearance do not behave in the same manner after harvest. This is particularly problematical for those involved in sales to the "ready-ripe" market. These operations are faced with a high variation in the rate of ripening within a consignment, causing logistical difficulties. Pearson ${ }^{(42)}$ reported that with increasing maturity the avocado oil content in the fruit increases while the water content or dry matter decreases. Landahl et al. ${ }^{(40)}$ stated that the oil content in the mesocarp and its composition vary within the fruit. On the other hand, their oil content is also influenced by cultivar type, cultural practices and environmental conditions. However, generally the oil content in the mesocarp is used as an indicator to harvest avocados. The presence of a minimum of $8 \%$ oil is used as a suitable maturity index value or indicator to harvest avocados. ${ }^{(43,44)}$ In many countries, traditionally, the oil content or dry matter of the mesocarp is used as a maturity indicator in avocados. ${ }^{(45)}$ The most accurate method adopted for oil determination was to dry the pulp (mesocarp) and then to employ the solvent extraction method to measure the oil content. ${ }^{(46)}$ However, this is a laborious method and it may take as long as $12 \mathrm{~h}$ or more to obtain the final results. Therefore, the avocado industry generally adopts two quantitative indices to harvest their fruit for export or domestic markets; the oil and moisture content indices. ${ }^{(47,48)}$ It was also asserted that the moisture content of the cultivar Pinkerton exported from South Africa must be between $80 \%{ }^{(49)}$ and $73 \%$ (Table 3). ${ }^{(50)}$ Wedding et al. ${ }^{(52)}$ described the potential of Fourier Transform-near infra-red spectroscopy in diffuse reflectance mode for non-invasive prediction of 
Table 3

Maximum moisture content of different avocado cultivars ${ }^{\mathrm{a}}$

\begin{tabular}{lc}
\hline Cultivar & Moisture content (\%) \\
\hline Fuerte & 80 \\
Hass & 77 \\
Pinkerton & 80 \\
Ryan & 80 \\
Lamb Hass & 73 \\
Maluma Hass & 78 \\
Nature's Hass & 77 \\
\hline
\end{tabular}

${ }^{\text {a }}$ Source: Kassim et al. ${ }^{(51)}$

the dry matter of whole 'Hass' fruit. Blakey et al. ${ }^{(41)}$ also used near infrared spectroscopy to measure mesocarp water content and postulated that on-line sorting of fruit using near infrared spectroscopy, based on time to ripen, would result in consignments of fruit with less ripening variation.

Lee et al. ${ }^{(55)}$ reported that the oil content is related to the taste of the fruit. However, according to Landahl et $a l^{(40)}$, the dry matter and the oil content of the mesocarp do not always correlate and Landahl et al. ${ }^{(40)}$ and Woolf $e t a l .{ }^{(54,45)}$ argued that depending on the growing areas, the dry matter within the fruit can vary. Furthermore, Hofman et al. ${ }^{(55)}$ maintained that there are no correlations between the dry matter content, the oil content and the fruit quality. The oil content 
in avocado fruit commonly ranges from 15 to $30 \%$ depending on the cultivar, and oleic acid was

found to be the predominant monounsaturated fatty acid contained therein. ${ }^{(56)}$ Oil content is therefore recommended as a suitable maturity index for cultivars that are rich in oil content whereas dry matter is also used for specific cultivars. For cultivars grown in California, the percentage dry matter in the fruit was used commercially as a maturity index for harvesting avocados. ${ }^{(58)}$ The maturity standards were related to the percentage dry matter and were developed for cultivars grown in California such as 'Bacon' (18.5\%), 'Fuerte' (19.9\%), 'Gwen' (25.9\%), 'Hass' (21.6\%), 'Pinkerton' (23.0\%), 'Reed' (19.8\%), 'Zutano' (18.8\%). ${ }^{(57)}$ For 'Hass', complementary indices such as flesh softening, which is related to skin color changes, are also included in the maturity index. For example, the green skin color (immature stage) changes to purple at the most suitable mature stage.

\section{Pre-harvest factors that affect postharvest quality of avocados}

Postharvest quality of the fruit develops during growth and maturation and is maintained, not improved, by postharvest conditions. There are several pre-harvest factors which if not well managed can severely affect the quality of the fruit. Understanding these factors and how they can be managed can to help minimize postharvest losses of avocado fruit. A summary of the preharvest factors that have an inherent effect on the postharvest quality of the fruit is shown in Table 4. 
Table 4

Pre-harvest factors that affects the postharvest quality of avocados ${ }^{\mathrm{a}}$

\begin{tabular}{|c|c|c|}
\hline Pre-harvest factor & Postharvest effect on fruit quality & Management \\
\hline $\begin{array}{l}\text { Climate or environment: } \\
\text { temperature, wind and rainfall }\end{array}$ & $\begin{array}{l}\text { Increased disease incidence, } \\
\text { chilling injury }\end{array}$ & $\begin{array}{l}\text { Pruning to expose the fruit to direct } \\
\text { sunlight }\end{array}$ \\
\hline Rootstock or scion & $\begin{array}{l}\text { Susceptibility to physiological } \\
\text { disorders during the cold chain, } \\
\text { postharvest decay }\end{array}$ & $\begin{array}{l}\text { Choose less susceptible rootstock } \\
\text { or scion }\end{array}$ \\
\hline Pruning practices & Poor fruit storability & $\begin{array}{l}\text { Strike a balance between } \\
\text { vegetative and reproductive growth } \\
\text { and correct timing is important }\end{array}$ \\
\hline Pest and disease management & $\begin{array}{l}\text { Changes in fruit composition, } \\
\text { influences the ripening behaviour } \\
\text { and decay development } \\
\text { (anthracnose), }\end{array}$ & $\begin{array}{l}\text { Maintain a clean orchard and } \\
\text { correct application of chemicals is } \\
\text { important }\end{array}$ \\
\hline Plant nutrition (N/Ca) & $\begin{array}{l}\text { Development of physiological } \\
\text { disorders (mesocarp discoloration } \\
\text { or grey pulp) and rots }\end{array}$ & $\begin{array}{l}\text { Manage vegetative growth and } \\
\text { avoid excessive nitrogen during } \\
\text { fruit development }\end{array}$ \\
\hline Plant growth regulators & Poor storability & Manage vegetative growth \\
\hline Irrigation & $\begin{array}{l}\text { Influences polyphenol oxidase } \\
\text { levels thus mesocarp discoloration }\end{array}$ & $\begin{array}{l}\text { Avoid water stress during fruit } \\
\text { growth and development }\end{array}$ \\
\hline
\end{tabular}

${ }^{\mathrm{a}}$ Source: Lu Arpaia et al. ${ }^{(61)}$ 


\section{Avocado postharvest chain management}

\section{Harvesting}

Fruit must be harvested without mechanical damage (cuts, scratches and abrasions), which can affect the cosmetic appearance of the fruit and act as an entry point for postharvest pathogens that cause decay during storage and transportation. ${ }^{(59)}$ Bruising can also cause localised softening. The usual method of harvesting involves the fruit being placed either into a soft picking bag attached to a harvesting pole or directly into a plastic crate to prevent damage to the fruit. For tall trees, hand picking poles or ladders are used for fruit that cannot be reached easily from the ground. Picking poles must have a clipper or knife attached to the end, with a catching or collection bag made of cloth. Directly after harvesting, the fruit must be moved to the shade in order to reduce weight loss due to moisture loss that will occur rapidly when they are exposed to the sun. It is usually recommended that avocado fruit should reach the packhouse within two hours of picking. The use of clippers is suitable for removing fruit from trees; however, it is recommended that about $1 \mathrm{~cm}$ of the pedicel should be left attached to the fruit. Harvesting methods were shown to affect the postharvest fruit quality of 'Fuerte' for which pedicels must be manually clipped. On the other hand 'Hass' can be snap-picked without causing an undesirable effect on their fruit quality. ${ }^{(59)}$ It is, however, well established that fruit cannot be harvested during wet weather conditions because the presence of water droplets on the fruit surface can

favor the incidence of postharvest diseases during distribution and storage ${ }^{(60)}$ and 'Fuerte' and 'Hass' harvested during wet conditions exhibited significant lenticels damage in comparison to fruit picked in dry weather. However, lenticels damage does not affect 'Hass' fruit quality because the fruit turns dark purple in color during ripening and the lenticels damage cannot be seen clearly in purple background. Generally, the occurrence of lenticels damage is higher for all 
the fruit picked early in the season. ${ }^{(59)}$ Incidences of vascular browning were also reported to be higher in fruit harvested when they are wet. ${ }^{(59)}$ For example, the incidences of vascular browning increased significantly in 'Hass' picked during wet conditions and late in the season when compared to the fruit picked during dry weather conditions or early in the season. $(56,61)$ Furthermore, fruit picked late was reported to ripen much faster, particularly when grown in warmer areas. ${ }^{(62)}$

\section{Field handling}

After harvesting, the avocado fruit must be carefully transferred from the picking bag into the field crates in order to avoid mechanical injuries, especially bruising. ${ }^{(63)}$ The fruit should not be placed on the ground so as to avoid any contact with the soil. This will help to prevent contamination by foodborne pathogens that can survive in the soil such as Listeria monocytogenes. ${ }^{(64)}$ Generally, PH Bulletin No. $18^{(63)}$ commented that large wooden crates that hold approximately $11 \mathrm{~kg}$ of fruit were the preferred type of field container. These containers should not be overfilled and must be placed in a shaded area and protected from direct sun. ${ }^{(65)}$ Exposure to the sun will tend to increase the pulp temperature, which accelerates ripening and shortens the shelf life of the fruit. ${ }^{(62,63,65)}$ 


\section{Sorting and grading}

At the packhouse, fruit from the orchard is sorted and graded according to the following commonly used quality criteria for grading avocados: size, skin color, and the absence of cuts or wounds, blemishes, insect damage and spray residue. Moreover, after ripening, the fruit must be free from diseases (anthracnose and stem-end rot), physiological disorders (grey pulp, vascular browning) and bruising. ${ }^{(67)}$

\section{Pre-cooling}

It is highly recommended that fruit be cooled as soon as possible after harvesting in order to delay ripening and related softening. Pre-cooling is very important, especially when the field temperatures are high $\left(>25^{\circ} \mathrm{C}\right)$. On arrival, the fruit must be pre-cooled to about $16^{\circ} \mathrm{C}$ in order to remove the field heat. Commercially, hydro cooling is the most common method used.

\section{Fungicide treatment and waxing}

At the packhouse and after cooling, the fruit is commonly treated with a fungicide. For example, diseases of avocados that can occur are controlled by Sportak (prochloraz $450 \mathrm{~g}$ a.i. $\left.\mathrm{L}^{-1}\right)^{(68)}$, especially in the commercial packhouse of South Africa, New Zealand and Australia. ${ }^{(69-71)}$ Prochloraz, a nonsystemic fungicide, is used as a first defense mechanism in the packing line to control postharvest diseases such as anthracnose and stem-end rot in avocados. It affects the mycelial growth of the pathogens and acts as a sterol inhibitor impeding the ergesetrol (fatty acid) synthesis, which is an important component of the fungal cell wall. Prochloraz ultravolume spray applications followed by a polyethylene wax coating were reported to reduce postharvest rots in avocados. ${ }^{(72)}$ 
Prochloraz is the only fungicide registered in South Africa for postharvest applications. At present, a dip of $200 \mathrm{ppm}$ prochloraz $+50 \mathrm{mM} \mathrm{HCl}$ is recommended and adopted by the Westfalia Technological Services to control anthracnose (this disease control is similar to the commercially applied prochloraz concentration, $810 \mathrm{ppm}) .{ }^{(73)}$

Waxing reduces moisture loss, may retard fruit softening and may also help to improve the surface appearance of fruit by adding shine and luster (e.g. in 'Fuerte') ${ }^{(74)}$; therefore, waxing is widely used in the South African avocado industry. According to Johnston and Banks ${ }^{(75)}$, waxes provide a surface barrier which hinders the movement of gases that can modify the internal atmosphere in the fruit. However, it has been demonstrated that waxing has some disadvantages including increased incidences of mesocarp discoloration ${ }^{(76)}$ and extended delays in fruit ripening associated with softening after cold storage ${ }^{(77)}$ in avocados. Commercially, Avoshine ${ }^{\circledR}$ carnauba wax coating is used for avocados. ${ }^{(78-80)}$ Green-skinned cultivars may develop surface discoloration if the proper wax formulation and application methods are not employed. A shellac or carnauba-based food-grade wax works well and has been applied mechanically by roller brushes in the past. ${ }^{(63)}$ However, the effectiveness of a wax application depends on many factors, for example, the concentration strength of the wax formulation; method of application, spraying or dipping; and the duration of the application. Avocados that have been waxed, which slowed ripening have been shown to develop more ripe rots than non-waxed fruit that ripened quicker. Biocoat $^{\mathrm{TM}}$ (a suspension mixture of beeswax and olive oil) extended the shelf life of avocado fruit ${ }^{(81)}$ but was ineffective in reducing ripe rots to commercially acceptable levels in late season 'Hass' avocado fruit. ${ }^{(82)}$ It also is essential that the applied wax coating must not leave any deleterious residues or affect the natural glossiness of the fruit, the eating quality or alter the characteristic fruit flavor. On the other hand, it has been reported that the managers of ripening 
facilities prefer fruit that are not waxed because waxing may result in "checkerboard ripening" (Personal communication van Rooyan Westfalia Technological Services, SA). The EU does not allow morpholine, a synthetic compound used as a solvent for resins and dyes in wax emulsions. ${ }^{(83)}$ There is some resistance to waxing of fruits including avocados in the EU due to consumer pressure.

\section{1-methylcyclopropene (1-MCP) treatment}

1-MCP is an ethylene inhibitor that has been approved in many countries as a postharvest treatment to delay ripening and ensure that fruit are less susceptible to extraneous accidental exposure to ethylene. In South Africa, 1-MCP treatment is used for late season fruits (personal communication Van Rooyan Westfailia Estates). Treatment of the avocado cultivars Gold Nijisseiki and Hosui with 1-MCP was effective in prolonging long term cold storage. ${ }^{(84)}$ Preclimacteric 'Booth 7' fruit were treated for 1 minute with aqueous 1-MCP at 1.86 and 9.3 $\mathrm{mmol} \mathrm{m} \mathrm{m}^{-3}$ one day after harvest when their ethylene production was less than $0.05 \mathrm{ng} \mathrm{kg}^{-1}$ second $^{-1}$. Both concentrations strongly suppressed softening, delayed ethylene production and delayed the climacteric peak. Seven days after harvest, when the ethylene production was $65 \%$ of maximum and the fruit were considered mid-climacteric, there was a complete loss of sensitivity to $1-\mathrm{MCP}$ at $1.86 \mathrm{mmol} \mathrm{m}^{-3}$ or at $9.3 \mathrm{mmol} \mathrm{m}^{-3}$. ${ }^{(85)}$ There was improved efficacy of 1-MCP at elevated doses and following reduction of internal ethylene concentration in suppressing ripening of mid-climacteric fruit. They considered that this was consistent with ethylene strongly influencing 1-MCP sensitivity in climacteric fruit that have been initiated to ripen. Zhang et $a l .{ }^{(86)}$ found that treatment of the cultivar 'Booth 7' with 1-MCP resulted in delayed 
accumulation of antioxidant chemicals and enzymes and that increasing doses of 1-MCP (over the range of 0.93 and $9.3 \mathrm{mmol} \mathrm{m}^{-3}$ ) increasingly delayed ripening at $20^{\circ} \mathrm{C}$.

Interactions between 1-MCP and waxing have been observed. For example, preclimacteric 'Tower II' and 'Booth 7' cultivars were treated with 1-MCP for 12 hours at $20^{\circ} \mathrm{C}$ and then half of the fruit were waxed with Sta-Fresh $819 \mathrm{~F}^{\circledR}$ (FMC Company, USA) after 1-MCP treatment. ${ }^{(87)}$ The fruit were subsequently stored at $13{ }^{\circ} \mathrm{C}$ or $20{ }^{\circ} \mathrm{C}$ at $85 \%$ RH. 1-MCP and waxing delayed the ripening of 'Tower II' stored at $20{ }^{\circ} \mathrm{C}$. Fruit treated with both 1-MCP and wax had better retention of green peel color and fruit firmness, and the treatments delayed the climacteric pattern of ethylene evolution and respiration rates. Waxing reduced weight loss and retarded softening, but did not delay climacteric patterns of ethylene evolution and respiration rates. Firmness of untreated fruit decreased from $>100 \mathrm{~N}$ to $20 \mathrm{~N}$ in as few as 7 days at $20{ }^{\circ} \mathrm{C}$, whereas fruit treated with both 1-MCP and wax reached $20 \mathrm{~N}$ only after 11 days at $20{ }^{\circ} \mathrm{C}$. The firmness of 'Booth 7' treated with both 1-MCP and wax decreased from $>170 \mathrm{~N}$ to $20 \mathrm{~N}$ over a 5-week period at $13{ }^{\circ} \mathrm{C}$.

\section{Packing and palletization}

It is essential for the packhouse to conduct fruit maturity tests. According to the South African Avocado Growers Association (SAAGA) ${ }^{(46)}$, fruit maturity needs to be tested by taking ten randomly harvested fruit from an orchard. The fruit is then categorised according to different grades according to size and appearance and packed into $4 \mathrm{~kg}$ cartons in a single layer. Avocado fruit is also packed for the domestic markets in pre-packed units; in plastic bags and in tray packs over-wrapped with cling film. Packhouse workers must wear gloves in order to prevent contamination by foodborne pathogens and mechanical damage (bruising or scratches) that are 
likely to occur during handling. The packhouse sorting or grading tables must be clean and smooth. The fruit stem of each fruit must be trimmed with the help of a sharp knife to a length of $6 \mathrm{~mm}$ to $12 \mathrm{~mm}$.

\section{Quality assurance in relation to packaging and transportation}

In South Africa, export fruit must be graded according to the quality criteria of the Perishable Products Export Control Board (PPECB) ${ }^{(88)}$ Quality standards for exports are determined by the Department of Agriculture, Forestry and Fisheries (DAFF) in conjunction with SAAGA. Quality inspections are carried out by the PPECB prior to shipping of the exports. One of the primary functions of the PPECB is to ensure that standards for refrigerated road transport and refrigerated containers adhere to the prescribed regulations and standards. In addition, growers of avocados have to comply with Good Agricultural Practice (GAP) standards. The SAAGA reports indicate that $95 \%$ of the industry is Europe Gap accredited. Other accreditations in the industry include BRC, LEAF, Fair-trade and Tesco's Nature's Choice. ${ }^{\left({ }^{9}\right)}$ Packaging cartons must include information cultivar, exporter, and locality of origin, average fruit weight. The packaging should also include grower codes for traceability in case of problems such as dirt discards and quality defects, Packer codes (to monitor productivity and accuracy) and data codes are important to monitor the time and temperature chain involved in the fruit export. Packing is in $370 \times 285 \mathrm{~mm}$ area top (outside diameter) cartons. ${ }^{(46)}$ Adequate ventilation during palletization is also recommended. Palletization is carried out on a pallet with dimensions of $1114 \times 1110 \mathrm{~mm}$, and the cultivar 'Fuerte' is generally packed with 252 boxes on each pallet pallet. ${ }^{(46)}$ 


\section{Temperature and relative humidity management}

The postharvest life of avocados is extended in cold storage by maintaining the overall quality parameters such as texture, taste and nutritional composition during the supply chain. A low temperature has a direct effect on their respiration rate, which is an indication of the rate of perishability. For every $10{ }^{\circ} \mathrm{C}$ increase in temperature the respiration rate approximately doubles and the primary metabolic substrates (sugars and organic acids) are depleted at an increasingly faster rate. Storage life varies inversely with respiration rate; therefore, the shelf life of avocados is shortened at higher temperatures. Low temperature storage slows the climacteric increase in $\mathrm{CO}_{2}$ and $\mathrm{C}_{2} \mathrm{H}_{4}$ production that occurs with ripening. Multiple enzymes that are involved in the synthesis of $\mathrm{C}_{2} \mathrm{H}_{4}$, carbohydrates, organic acids and volatile compounds are inhibited at lower temperatures, and consequently, ripening-related changes in color, flavor, texture and aroma are delayed. Various temperatures are recommended to extend the shelf life of avocados varying from about 5 to $13{ }^{\circ} \mathrm{C} .{ }^{(90)}$ It is also important to maintain the packhouse temperature and therefore, the PPECB applies a grading system for cooling facilities in packhouse. The recommended fruit pulp temperature is above $3{ }^{\circ} \mathrm{C}$ and the recommended shipping temperature is achieved 24 hours after harvesting.

Temperature recommendations for cold storage vary with race, cultivar, maturity or ripeness and harvest season but generally include 5 to $10{ }^{\circ} \mathrm{C}$ and $90 \% \mathrm{RH}$ for 2 to 4 weeks ${ }^{(91)}$, Therefore, avocados should be stored at $8{ }^{\circ} \mathrm{C}$ to extend their shelf life. Alternatively avocados can be stored at 8 to $12{ }^{\circ} \mathrm{C}$ and 85 to $90 \% \mathrm{RH}$ for 2 to 4 weeks for unripe fruit and 5 to $8{ }^{\circ} \mathrm{C}$ and 85 to $90 \% \mathrm{RH}$

for 1 to 2 weeks for ripe fruit (Table 5). ${ }^{(92)}$ Saucedo Veloz et al $\left({ }^{(96)}\right.$ reported that storage at $5{ }^{\circ} \mathrm{C}$ for 6 weeks followed by 4 days at $20{ }^{\circ} \mathrm{C}$ resulted in excessive softening, browning and storage rots while $2{ }^{\circ} \mathrm{C}$ for 6 weeks followed by 4 days at $20{ }^{\circ} \mathrm{C}$ resulted in fruit of better quality. 


\section{Table 5}

Recommended storage conditions for specific avocado cultivars

\begin{tabular}{|c|c|c|c|c|c|}
\hline Cultivar & Ripe or unripe & Temperature & Relative humidity & Duration & Source \\
\hline 'Booth 1' (Guatemalan x West Indian hybrid) & Unripe & $4.5^{\circ} \mathrm{C}$ & 85 to $90 \%$ & 2 to 4 weeks & $(93)$ \\
\hline 'Booth 1' & Unripe & $4{ }^{\circ} \mathrm{C}$ & 90 to $95 \%$ & 4 to 8 weeks & $(94)$ \\
\hline 'Fuchs' (West Indian) & Unripe & $12.8^{\circ} \mathrm{C}$ & 85 to $90 \%$ & 2 weeks & $(95)$ \\
\hline 'Fuchs' & Unripe & 10 to $13{ }^{\circ} \mathrm{C}$ & 85 to $90 \%$ & 2 weeks & $(93)$ \\
\hline 'Fuerte' (Mexican x Guatemalan hybrid) & Unripe & 5.5 to $8{ }^{\circ} \mathrm{C}$ & 85 to $90 \%$ & 3 to 4 weeks & $(93)$ \\
\hline 'Fuerte' & Ripe & 2 to $5{ }^{\circ} \mathrm{C}$ & 85 to $90 \%$ & 1 to 2 weeks & $(93)$ \\
\hline 'Fuerte' & Ripe & 3 to $7{ }^{\circ} \mathrm{C}$ & 85 to $90 \%$ & 2 to 4 weeks & $(94)$ \\
\hline 'Hass' (Guatemalan x Mexican hybrid) & Unripe & 5.5 to $8{ }^{\circ} \mathrm{C}$ & 85 to $90 \%$ & 3 to 4 weeks & $(93)$ \\
\hline 'Hass' & Ripe & 2 to $5{ }^{\circ} \mathrm{C}$ & 85 to $90 \%$ & 1 to 2 weeks & $(94)$ \\
\hline 'Hass' & Ripe & 3 to $7{ }^{\circ} \mathrm{C}$ & 85 to $90 \%$ & 2 to 4 weeks & $(96)$ \\
\hline
\end{tabular}

${ }^{\mathrm{a}}$ Source: Kader $^{(92)}$ 
Certain avocado cultivars were reported to be susceptible to chilling injury when stored below 13 ${ }^{\circ} \mathrm{C}\left({ }^{(97)}\right.$ Fruit stored below $8{ }^{\circ} \mathrm{C}$ may develop chilling injury and 'Hass' stored at $5{ }^{\circ} \mathrm{C}$ for 4 weeks had uneven ripening, distorted respiratory patterns and reduced ethylene peaks during subsequent ripening at $20^{\circ} \mathrm{C} .{ }^{(98)}$ Symptoms of chilling injury include pitting, browning of pulp near the seed or in the tissue midway between the seed and the skin, failure to soften when transferred to a higher temperature, off flavor, vascular strands and development of a brownish appearance. In other work, chilling injury was shown to occur at 10 to $11.1^{\circ} \mathrm{C}$ for cultivars of the West Indian race and 4.4 to $6.1{ }^{\circ} \mathrm{C}$ for the Mexican and Guatemalan races. ${ }^{(99)}$ In a study of avocados from trees propagated from seed in Grenada, Thompson et al. ${ }^{(100)}$ showed that there was considerable variation in storage life and chilling injury symptoms between fruit from different trees. It meant that even at $7{ }^{\circ} \mathrm{C}$ some $77 \%$ of the fruit ripened without showing symptoms of chilling injury and at $13{ }^{\circ} \mathrm{C}$ some $27 \%$ actually suffered from chilling injury. However, it does seem clear that the Mexican and Guatemalan races are less susceptible to chilling injury than the West Indian race. Controlled atmosphere storage can affect susceptibility to chilling injury. There were less chilling injury symptoms in 'Booth 8', 'Lula' and 'Taylor' after refrigerated storage in controlled atmospheres than in refrigerated storage in air. ${ }^{(94,96,99,101)}$ Corrales-Garcia ${ }^{(102)}$ found that 'Hass' stored at 2 or $5{ }^{\circ} \mathrm{C}$ for 30 days in air, $5 \% \mathrm{CO}_{2}$ with $5 \% \mathrm{O}_{2}$ or $15 \% \mathrm{CO}_{2}$ with $2 \% \mathrm{O}_{2}$ had higher chilling injury for fruits stored in air than the fruits in controlled atmosphere storage, especially those stored in $15 \% \mathrm{CO}_{2}$ with $2 \% \mathrm{O}_{2}$. Spalding and Reeder ${ }^{(103)}$ showed that storage of fruits at either $0 \% \mathrm{CO}_{2}$ with $2 \% \mathrm{O}_{2}$ or $10 \% \mathrm{CO}_{2}$ with $21 \% \mathrm{O}_{2}$ fruit had less chilling injury and less anthracnose during storage at $7{ }^{\circ} \mathrm{C}$ than fruits stored in air. Intermittent exposure of the cultivar 'Hass' to $20 \% \mathrm{CO}_{2}$ increased their storage life at $12^{\circ} \mathrm{C}$ and reduced chilling injury during storage at $4{ }^{\circ} \mathrm{C}$ compared to those stored in air at the same temperatures. ${ }^{(104)}$ 
Fuerte avocados will ripen normally at temperatures between 9 and $24{ }^{\circ} \mathrm{C}$, but in the presence of $100 \mu \mathrm{L} \mathrm{L}^{-1}$ ethylene, chilling injury occurred at $12{ }^{\circ} \mathrm{C} .{ }^{(105)}$ Application of calcium to avocados could reduce their susceptibility to chilling injury during subsequent storage. ${ }^{(106)}$ Fruits stored for 4 to 10 weeks at $2{ }^{\circ} \mathrm{C}$ had reduced severity of chilling injury symptoms and percentage of injured fruits after they had been dipped for 30 seconds in methyl jasmonate at $2.5 \mu \mathrm{M}$ for 'Fuerte' and 'Hass' and $10 \mu \mathrm{M}$ for 'Etinger'. (107)

Heat treatments (hot air or hot water) have been shown to reduce the chilling injury in some tropical fruits. Hot air treatments at $38{ }^{\circ} \mathrm{C}$ for up to $10 \mathrm{~h}$ or hot water treatments from 39 to $42{ }^{\circ} \mathrm{C}$ prevented chilling injury in avocados. ${ }^{(108-110)}$ Heat treatments also helped to reduce chilling injury by stimulating the development of heat shock proteins, which play a major role in protecting cell integrity and provide thermo-tolerance to many horticultural commodities. ${ }^{(111-113)}$ It has been demonstrated that heat shock protein production prevented irreversible protein denaturation in fruit in response to high temperature exposure, but presented a temporary resistance to sub-lethal temperatures. Hot air treatments were reported to increase the expression of heat shock protein genes and protein accumulation in avocados. ${ }^{(114)}$ As observed by Ouma ${ }^{(115)}$, heating avocados to $38{ }^{\circ} \mathrm{C}$ for periods of 24,48 or $72 \mathrm{~h}$ improved their appearance and reduced the effects of chilling injury as opposed to untreated fruit. Ouma ${ }^{(115)}$ also showed that ethylene production was delayed, the rate of respiration remained unchanged, and the weight loss was reduced as the number of days of heating increased. This in turn improved the shelf life of the fruit. The polygalacturonase and $\beta$-galactosidase activities were reduced by heat treatments, whereas an enhanced pectin methyl esterase activity was observed. ${ }^{(116)}$

The optimum storage temperature is also a function of fruit maturity and the physiological stage of fruit development. Mature fruit picked early in the season is much more susceptible to low 
storage temperatures and more likely to suffer from chilling injury ${ }^{(117,118)}$ and were observed to store best at $7.5^{\circ} \mathrm{C}$. Swarts ${ }^{(119)}$ concluded that the effects of chilling injury in early season fruit is not due to fruit maturity but rather to a decrease in orchard temperature to below $17{ }^{\circ} \mathrm{C}$. Storage at 5 to $6{ }^{\circ} \mathrm{C}$ for 28 days was recommended for 'Fuerte' and 'Hass', both non-West Indian cultivars, before the onset of physiological disorders. ${ }^{(120)}$ They also reported that lowering the storage temperature may increase the incidence of external chilling injury but can help to reduce the discoloration of the edible portion. Van Rooyen and Bower ${ }^{(121)}$ and Van Rooyen ${ }^{(122)}$ showed that mesocarp discoloration was reduced in green cultivars at $2{ }^{\circ} \mathrm{C}$ and in a purple cultivar (Hass) at $1{ }^{\circ} \mathrm{C}$. According to Swartz ${ }^{(119)}$, a proposal was made to store early season fruit at higher temperatures $\left(7.5^{\circ} \mathrm{C}\right)$ and the mid and late season fruit at $5.5^{\circ} \mathrm{C}$ or even lower..$^{(123)}$

The maintenance of a high humidity is also important because avocados, like other fruit, are susceptible to shrivelling. Therefore, it is recommended that avocados be stored at 90 to $95 \% \mathrm{RH}$ to prevent weight loss and skin desiccation. Weight loss is directly related to water loss, which takes place through the stomata, stem scar and cuticle; the amount of water loss depends on cuticle composition and thickness, which varies for cultivars and maturity stage. However, a high humidity may promote decay development, especially if moisture condenses on the fruit (sweating) over long periods of time when temperatures fluctuate during transportation. Therefore, for the efficient marketing of avocados the participants in the supply chain need to understand and maintain optimum temperatures and humidity in order to retain the overall fruit quality. 


\section{Fruit ripening}

Unlike probably all other climacteric fruit, avocados do not ripen until they have fallen naturally from the tree or have been harvested. They can remain in a mature but unripe condition on the tree for considerable periods. ${ }^{(23)}$ Ripening involves softening of the flesh and a change in skin color for certain cultivars. The rate of ripening after harvesting is determined by the harvest maturity of the fruit, the temperature and exposure to ethylene. West Indian avocado cultivars ripen best at temperatures between $16{ }^{\circ} \mathrm{C}$ and $24{ }^{\circ} \mathrm{C}$. At higher temperatures, fruit ripens unevenly, develops off-flavors and influences the development of postharvest decay. In fact, Biale and Young ${ }^{(124)}$ showed that at both $5{ }^{\circ} \mathrm{C}$ and $30{ }^{\circ} \mathrm{C}$ no climacteric rise in respiration occurred in a Mexican and Guatemalan hybrid, but a climacteric occurred at all the intervening temperatures. General recommendations include 18 to $21^{\circ} \mathrm{C}$ with exposure to $10 \mu \mathrm{L} \mathrm{L}^{-1}$ of ethylene for 24 to 72 hours ${ }^{(125)}$ and $15.5^{\circ} \mathrm{C}$ as the optimum temperature for ripening Florida avocados. ${ }^{(121,126)}$ Ripening fruit at lower temperatures, for example 15 to $20{ }^{\circ} \mathrm{C}$, can lead to significant reduction in rots compared with ripening at higher temperatures. ${ }^{(127)}$ Treatment with $100 \mathrm{ppm}$ ethylene at $20{ }^{\circ} \mathrm{C}$ for 24 to $48 \mathrm{~h}$ was shown to initiate avocados to ripen within three to six days. Early season mature fruit may take 10 to 12 days to ripen at $20{ }^{\circ} \mathrm{C}$, whereas mature fruit harvested late in the season may ripen within five to six days in the same conditions. Unripe avocados must not be stored with ethylene-producing crops if required to be in a firm unripe

condition. Soft ripe fruit has a shelf life of only 3 days. ${ }^{(128)}$ Optimum ripening conditions may also vary with cultivars and harvest season. For example Yahia ${ }^{(94)}$ reported that for the cultivar 'Hass' in New Zealand ripening at 17 to $20^{\circ} \mathrm{C}$ with 10 to $100 \mu \mathrm{L} \mathrm{L}^{-1}$ of ethylene was optimum, but for early season fruits, 2 to 3 days exposure time was required but only 1 to 2 days for late season fruit. In South Africa, according to the Westfalia Technological Services, fruit are ripened 
at 18 to $20{ }^{\circ} \mathrm{C},>90 \% \mathrm{RH}$ with $100 \mathrm{ppm}$ ethylene for $24 \mathrm{~h}$ cycles. Every 24 hours the rooms are ventilated and the progress of ripening is monitored. Generally, under these conditions, fruit ripens after 4 to 7 days (Personal communication van Rooyan Westfalia Technological Services, SA). During ripening, the air flow and $\mathrm{CO}_{2}$ are monitored. The ripened fruit is then stored at $5{ }^{\circ} \mathrm{C}$ overnight before dispatch.

\section{Postharvest quality loss and management}

The major causes of postharvest quality losses along the marketing chain are due to mechanical injury that occur during harvesting, field handling or transportation, as well as over-ripe fruit, desiccated fruit, postharvest diseases (anthracnose and stem-end rots), and chilling injury as a result of improper storage temperatures, pest damage, and physiological disorders. These factors affect the appearance, texture, taste, and nutritional value of the fruit; for example, loss of firmness and chilling injury were the main limitations in the retail quality for avocados subjected to fluctuating temperatures (too cold or too warm) during a simulation of the shipping and handling of the fruit. ${ }^{(28) .}$

\section{Postharvest diseases}

The postharvest life of avocados is affected by fungal pathogens; therefore, postharvest diseases become a major constraint for successful storage and shipments. Anthracnose and stem-end rot are two major postharvest diseases that cause serious losses during exports. ${ }^{(129)}$ Diseases of avocado fruit that have been reported are shown in Table 6. Five fungi have been identified as being important pathogens of avocado in New Zealand. ${ }^{(131)}$ These are Colletotrichum acutatum, 
Table 6

Postharvest diseases of avocado fruit ${ }^{\mathrm{a}}$

\begin{tabular}{|c|c|}
\hline Common name & Causal agent \\
\hline Anthracnose & $\begin{array}{l}\text { Colletotrichum gloeosporiodes. (the conidial stage of Glomerella cingulata (Stonem.) Spauld \& } \\
\text { Schrenk) }\end{array}$ \\
\hline \multirow[t]{3}{*}{ Stem end rot } & Botryodiploidia theobromae Pat, \\
\hline & Dothiorella spp. \\
\hline & Thyronectria pseudotrichia (Schw.) Seeler \\
\hline Alternaria rot & Alternaria sp \\
\hline Rhizopus rot & Rhizopus stolonifer (Ehrenb. Ex Fr.) Lind \\
\hline Rusty blight & Colletotrichum gloeosporioides (Penz.) Penz. \& Sacc. in Penz., C. nigrum Ellis \& Halst. \\
\hline Scab & Sphaceloma perseae Jenkins \\
\hline Sooty blotch & Akaropeltopsis sp. \\
\hline Fusarium rot & Fusarium spp. \\
\hline Pestaloptiopsis rot & Pestaloptiopsis versicolor (Spreg.) Steyart \\
\hline Phytophthora rot & Phytophthora citricola Sawada \\
\hline Pink mould, pink rot & Trichothecium roseum Link. synonymous with Cephalothecium roseum Corda. \\
\hline Botryodiplodia rot & $\begin{array}{l}\text { Botryodiplodia sp. Botryosphaeria obtusa (Schwein.) Shoemaker B. quercuum (Schwein.) Sacc. } \\
\text { B. rhodina (Cooke) Arx. Botrytis cinerea Pers.:Fr. synonymous with B. vulgaris Link:Fr. } \\
\text { Botryotinia fuckeliana (de Bary) Whetzel [teleomorph]. }\end{array}$ \\
\hline $\begin{array}{l}\text { Cercospora spot or } \\
\text { blotch }\end{array}$ & Pseudocercospora purpurea (Cooke) Deighton \\
\hline Dothiorella rot & Botryosphaeria ribis Grossenb. \& Duggar conidial stage Dothiorella gregaria Sace. \\
\hline Bacterial soft rot & Erwinia carotovora Jones \\
\hline & Psuedomonas syringae pv syringae van Hall. \\
\hline Blue mould & Penicillium expansum Link. \\
\hline
\end{tabular}

${ }^{\mathrm{a}}$ Source: Manicom ${ }^{(129)}$ and Smilanick 
C. gloeosporioides, Botryosphaeria parva, B. dothidea and Phomopsis sp. Each of these fungi can cause postharvest diseases of avocado, infecting either through the side of the fruit (body rots) or through the picking wound (stem-end rots). Hartill ${ }^{(131)}$ reported two major post-harvest diseases have been found in New Zealand avocados: anthracnose, associated with Colletotrichum spp., and stem-end rots, associated with Botryosphaeria and Phomopsis species. Several Fusarium species have been also isolated from fruit rots. Scab (Sphaceloma perseae Jenkins) was recorded for the first time on New Zealand avocados ${ }^{(68)}$

The susceptibility of the fruit to disease development

The cultivar Hass grafted onto Duke 6 rootstock and 'Hass' fruit with low calcium concentrations are more susceptible to anthracnose development with the result that the postharvest fungicide treatment may not be effective. ${ }^{(125,130)}$ In order of frequency, Colletotrichum, Dothiorella, Alternaria and Phomopsis spp. were isolated from decayed California avocados. ${ }^{(136)}$ The most prevalent fungi responsible for postharvest diseases in New Zealand were reported to be Colletotrichum acutatum, C. gloeosporioides, Botryosphaeria parva, B. dothidea and Phomopsis. ${ }^{(131)}$ Anthracnose caused by C. gloeosporiodes, and a lenticular rot caused by Dothiorella gregaria can infect the fruit in the field and develop during postharvest storage. ${ }^{99)}$ However, fungal infections were found to be associated only with area of primary damage, except where fruits were overripe where the most common organism was $B$. theobromae. ${ }^{(100)}$ Infections can also occur postharvest through the cut stalk ${ }^{(99)}$ and in the past some exporters dabbed a blob of candle wax on the cut stalk, but no objective studies have been found that confirm its effectiveness. 


\section{Post harvest diseases control}

\section{Fungicide application and related issues}

For control of anthracnose and stem-end rot diseases, fruit should be treated with prochloraz (an amide fungicide) within $24 \mathrm{~h}$ of harvest applied as a nonrecirculated spray over fruit on rollers or brushes. Both field spraying and postharvest treatments are necessary to achieve high quality fruit. Copper sprays are used in the orchard and prochloraz is applied postharvest. ${ }^{(69)}$ Limited control of the anthracnose disease can be achieved with an application of pre-harvest copper oxychloride. The latter application leaves undesirable patches on the fruit surface and it is a timeconsuming process to remove them manually in the packhouse prior to packing. ${ }^{(132)}$ Currently, the only fungicides registered for use on avocados in New Zealand are various copper formulations (e.g., copper hydroxide, copper oxychloride and copper sulphate) and prochloraz. Copper hydroxide inhibited spore germination on all the fungi they tested but only at high concentrations (2.4 to $11.6 \mu \mathrm{g} \mathrm{mL} \mathrm{m}^{-1}$ ). Benomyl did not inhibit spore germination of Botryosphaeria spp. Prochloraz and pyrimethanil (an anilinopyrimidine fungicide) were only effective against the Botryosphaeria spp. at the highest concentration tested (369.6, 913.1, 562.3 and $\left.1147.2 \mathrm{~g} \mathrm{~mL}^{-1}\right){ }^{(69)}$ Of the fungicides tested, prochloraz was the most effective inhibitor of mycelial growth of four of the five fungi tested (C. acutatum, C. gloeosporioides, B. dothidea and Phomopsis) at concentrations ranging from 0.29 to $0.36 \mathrm{~g} \mathrm{~mL}^{-1}$. Fluazinam was next most effective against C. acutatum and C. gloeosporioides at levels of 7.8 and $1.7 \mathrm{~g} \mathrm{~mL}^{-1}$, respectively.

The strobilurins were the next most effective fungicide group, and of these fungicides, kresoximmethyl (a methoxyiminoacetate strobilurin fungicide) was the most effective, at concentrations ranging from 0.1 to $1.9 \mu \mathrm{g} \mathrm{mL}^{-1}$. Strobilurin fungicides were extracted from the fungus and were 
first launched in 1996. They are mostly contact fungicides with a long half-life as they are largely only absorbed into the cuticle and not transported any further, although some of them have a low uptake in the leaves (e.g., azoxystrobin). Strobilurins inhibit respiration and inhibit a specific enzyme - succinate dehydrogenase. The best time to apply strobilurins is prior to infection or at very early stages of disease development. ${ }^{(133)}$ Willingham et al. ${ }^{()}$reported that strobilurin fungicides were effective in controlling postharvest diseases of 'Hass' avocado. Of the three strobilurin formulations tested in the field, the Amistar ${ }^{\circledR}$ and Flint ${ }^{\circledR}$ (both methoxyiminoacetamide strobilurin fungicides) fungicides were found to be superior to the Stroby ${ }^{\circledR}$ (a methoxyiminoacetate strobilurin fungicide) formulation. When Amistar ${ }^{\circledR}$ or Flint $^{\circledR}$ were sprayed on the trees the incidence of anthracnose was significantly reduced by $66 \%$ and $74 \%$, respectively. Working with the cultivar Hass, Willingham et al. ${ }^{(134)}$ found that the variety of rootstock had a significant impact on postharvest anthracnose susceptibility. The incidence of anthracnose was on average 34 to $35 \%$ lower for 'Hass' grafted on the Guatemalan Velvick rootstock as compared with the Mexican Duke 6 rootstock. They claimed that this was the first record of such an effect for avocado.

Consumers prefer purchasing fruit that is not treated with pesticides and that are free from defects, disease free and safe for consumption. On the other hand, the importing countries have enforced strict import regulations regarding the maximum residue limits (MRL) of chemicals in the edible portion of the fruit. The disposal of fungicide solutions used in large volumes can also affect the environment, especially the soil and water resources, and there is evidence of the development of resistant strains of pathogenic organisms to these chemicals. ${ }^{(132,135)}$ Due to green consumerism and an increasing demand for organically produced fruit and vegetables, the horticultural industry needs to find an alternative solution to postharvest fungicide applications. 
According to the food quality and safety report of the South African National Department of Agriculture and Fisheries (DAFF), the permissible MRL for prochloraz in South African avocados is $2 \mathrm{mg} \mathrm{kg}^{-1}{ }^{(136)}$ Therefore, research has focused on finding alternatives to replace the currently used prochloraz fungicide postharvest application in packhouse and this literature includes some important developments regarding this research. Also, postharvest chemical fungicide treatment is not permitted in some countries.

\section{Bio-control application}

Bacillus spp. on their own or combined with a fungicide could be used to control postharvest diseases of avocados. ${ }^{(137)}$ Bacillus spp. isolated from leaves and fruit of avocados were more effective in controlling anthracnose and stem end rot of avocados when applied as a postharvest dip than prochloraz applied in the same way and B. subtilis was just as efficient as prochloraz in controlling anthracnose postharvest. ${ }^{(137,138)}$ Microbial antagonist or bio-control agents are used on their own or in combination with a reduced concentration of synthetic fungicides. ${ }^{139)}$ For example, the combination of $B$. subtilis and prochloraz was more effective than when they were applied separately. The use of antagonistic microrganisms for bio-control purposes has emerged as a viable disease management strategy ${ }^{(140)}$. In South Africa, biological control research programs on avocado commenced in 1987 and the bio-control agent (Bacillus subtilis B246, Avogreen $\left.{ }^{\circledR}\right)^{(141)}$ was introduced to commercial avocado growers and is still being used by organic avocado growers. Enhanced disease control is achieved by incorporating B. subtilis in wax. However, the biggest challenge facing companies marketing bio-control products in South Africa is severe lack of technical knowledge regarding their handling and use. 


\section{Plant extracts and essential oils}

Regnier et al. ${ }^{(142)}$ tested Lippia scaberrima essential oil and three of the major oil components, (d)-limonene, R-(-)-carvone, and 1,8-cineole, as well as that of $\mathrm{S}-(+)$-carvone in vitro against $C$. gloeosporioides, Lasiodiplodia theobromae, and an Alternaria isolate. They found significant inhibition of the mycelial growth of all the pathogens when applied at a concentration of 2000 $\mu \mathrm{L} \mathrm{L}^{-1}$. They subsequently carried out a simulated export trial using L. scaberrima essential oil, in addition to Mentha spicata (spearmint) essential oil and concluded that they could be alternatives to synthetic fungicides for the postharvest management of avocado fruit that would be acceptable to the organic market. Combined application of modified atmosphere packaging $\left(\sim 8 \% \mathrm{CO}_{2}, 2 \% \mathrm{O}_{2}\right)$ and sachets containing thyme oil significantly reduced the incidence and severity of anthracnose, grey pulp, vascular browning, weight loss and loss of fruit firmness. These combination treatments also exhibited an acceptable taste, flavor, and texture, and a higher overall acceptance of the cultivars 'Fuerte,' ,'Hass' and 'Ryan' after ripening at $25{ }^{\circ} \mathrm{C}$ followed by cold storage at $10{ }^{\circ} \mathrm{C}$. The combination treatment MAP and thyme oil sachets was reported to delay ripening in avocados; with respect to the skin color, it clearly indicated changes in cv. 'Hass' ${ }^{(143)}$. Thyme oil $\left(66.7 \mu \mathrm{L} \mathrm{L}^{-1}\right)$ treatment was reported to enhance the activities of defense enzymes including chitinase, 1, 3- $\beta$-glucanase, peroxidise and phenylalanine ammonia-lyase resulting in an increase in the total phenolics content. The thyme oil $\left(66.7 \mu \mathrm{L} \mathrm{L}^{-1}\right)$ treatment also improved the activities of antioxidant enzymes (superoxide dismutase and catalase) and based on

these findings, Sellamuttu et al. ${ }^{(144)}$ suggested that the effects of thyme oil on anthracnose in the avocado fruit is due to the elicitation of biochemical defence responses in the fruit and inducing the activities of antioxidant enzymes. 


\section{Hot water treatment}

Postharvest heat treatments are recommended as nonpolluting, safe, physical treatments in order to control disease during storage and the marketing of fresh fruit. Heat treatments possess many advantages over chemical treatments: they do not leave any residue on or in the fruit, they can be implemented within a short duration, they are easily monitored, and the pathogens can be controlled even after gaining entry into the fruit. ${ }^{(139)}$ The use of postharvest heat treatments to control decay during storage needs to be applied within a short period after harvesting in order to prevent the entry or further penetration of the target pathogens found on the surface or in the first few cell layers under the skin of the fruit. Treatment temperatures and duration can be cultivar specific. Improper heat treatments in terms of unfavorable higher temperatures or increasing time of exposure could result in undesirable effects on the quality of the fresh produce. Hot water treatment is widely utilized in many countries for decay control because it is relatively easy to use and is usually cost-effective. ${ }^{(145)}$

Heat treatments control decay by directly inhibiting spore germination and mycelial growth, thereby inhibiting pathogen development. Heat treatments further induce defense responses such as increased biosynthesis and an accumulation of phytoalexins (specific plant antimicrobial compounds) via the activation of phenylalanine ammonia lyase (PAL EC 4.3.1.5.), the key enzyme of the phenylpropanoid pathway. ${ }^{(146)}$ Furthermore, heat treatments can increase the lignifications of cell walls in wound sites in order to provide physical barriers against invading pathogens. Heat treatments have also been shown to induce the production of pathogenesisrelated proteins and the accumulation of enzymes such as chitinase (hot water dip at $53{ }^{\circ} \mathrm{C}$ in grapefruit) $^{(147)}$ and $\beta$-1,3-glucanase to hydrolyse the fungal cell walls in order to inactivate the pathogens. ${ }^{(148,149)}$ In avocados, quantitative changes in the phytoalexin (1-acetoxy-2-hydroxy-4- 
oxo-heneicosa-12, 15-diene) and the anthracnose symptom development after hot water treatments at $55{ }^{\circ} \mathrm{C}$ for $10 \mathrm{~min}$ were reported by Plumbley et al. ${ }^{(150)}$ The concentration of 1 acetoxy-2-hydroxy-4-oxo-heneicosa-12, 15-diene at harvest was 2000 and $2600 \mu \mathrm{g} \mathrm{g}^{-1}$ fresh weight in the skin and mesocarp, respectively. The levels of diene were reported to decline rapidly during the first $24 \mathrm{~h}$ after harvesting and did not recover until $98 \mathrm{~h}$ in the skin. When hot water treated fruit was inoculated, the symptoms occurred after 2 days, whereas in untreated fruit relatively minor symptoms were noted after 6 days. However, when there was a delay in inoculation after hot water treatment the symptoms appeared only after 6 days. Based on these observations, Plumbley et al. ${ }^{(150)}$ conclude that the quiescence of $C$. gloeosporioides could be maintained by the level of antifungal diene present in the peel at the time of fungal penetration and the formation of subcuticular hyphae. Anthracnose development was also investigated in avocados treated with hot water at $55^{\circ} \mathrm{C}$ for $5 \mathrm{~min}, 50{ }^{\circ} \mathrm{C}$ for $10 \mathrm{~min}$ and $45^{\circ} \mathrm{C}$ for $15 \min$ by Karunaratne and Adikaram ${ }^{(151)}$. These researchers reported that the hot water treatment at $50{ }^{\circ} \mathrm{C}$ for $10 \mathrm{~min}$ failed to reduce anthracnose development whereas fruit treated at $45^{\circ} \mathrm{C}$ for 15 min on the day of harvesting, or 1 to 5 days after harvesting, resulted in a significant reduction in anthracnose symptom development. However, they found no significant difference in the antifungal compound 1-acetoxy-2- hydroxy-4-oxo-heneicosa-12, 15-diene between the hot water treated fruit at $45{ }^{\circ} \mathrm{C}$ for $15 \mathrm{~min}$ and those of the other treatments tested that could explain the reduction of anthracnose symptoms noted in the fruit subjected to $45^{\circ} \mathrm{C}$ for $15 \mathrm{~min}$. Table 7 shows a summary of alternative treatments to replace prochloraz fungicide application to control postharvest diseases in avocados. 
Table 7

Alternative treatments researched to replace prochloraz fungicide application to control postharvest diseases in avocados

\begin{tabular}{|c|c|c|c|}
\hline $\begin{array}{l}\text { Alternative treatments to control } \\
\text { postharvest diseases in avocados }\end{array}$ & $\begin{array}{l}\text { Description of postharvest } \\
\text { treatments }\end{array}$ & Target pathogen and the decay & Source \\
\hline $\begin{array}{l}\text { 1. Application of biocontrol agent } \\
\left(\text { Avogreen }^{(R)}\right)\end{array}$ & Bacillus subtilis B246, Avogreen $\left.{ }^{\circledR}\right)^{(}$ & C. gloeosporioides (anthracnose) & (134) \\
\hline 2. Hot water treatment & $\begin{array}{l}\text { at } 55^{\circ} \mathrm{C} \text { for } 10 \mathrm{~min} \\
\text { at } 45^{\circ} \mathrm{C} \text { for } 15 \mathrm{~min} \\
1 \text { to } 5 \text { days after harvesting }\end{array}$ & $\begin{array}{l}\text { C. gloeosporioides (anthracnose) } \\
\text { C. gloeosporioides (anthracnose) }\end{array}$ & $\begin{array}{l}(148) \\
(149\end{array}$ \\
\hline 3. Plant extract & Lippia scaberrima & $\begin{array}{l}\text { C. gloeosporioides (anthracnose) } \\
\text { Lasiodiplodia theobromae (stem-end rot) } \\
\text { Alternaria spp. }\end{array}$ & $(140)$ \\
\hline & Mentha spicata (spearmint) & $\begin{array}{l}\text { C. gloeosporioides (anthracnose) } \\
\text { Lasiodiplodia theobromae (stem-end rot) } \\
\text { Alternaria spp. }\end{array}$ & \\
\hline $\begin{array}{l}\text { 4. Combined applications of essential oil } \\
\text { and modified atmosphere packaging } \\
\text { (MAP) }\end{array}$ & $\begin{array}{l}\text { Thyme oil and MAP }\left(\sim 8 \% \mathrm{CO}_{2}, 2 \%\right. \\
\left.\mathrm{O}_{2}\right)(\end{array}$ & C. gloeosporioides (anthracnose) & $(141)$ \\
\hline 5. Controlled atmosphere storage & $\begin{array}{l}\text { Fuchs and Waldin stored at } 2 \% \mathrm{O}_{2} \text { and } \\
10 \% \mathrm{CO}_{2} \text { at } 7.2^{\circ} \mathrm{C} \text { for } 3 \text { to } 4 \text { weeks }\end{array}$ & C. gloeosporioides (anthracnose) & $(164)$ \\
\hline 6. Dynamic CA & & Fungal decay & $(167)$ \\
\hline 7. Hypobaric storage & $91 \mathrm{~mm} \mathrm{Hg}$ plus $10 \% \mathrm{CO}_{2}$ & $\begin{array}{l}\text { C. gloeosporioides (anthracnose) } \\
\text { stem end rot (Diplodia natalensis) }\end{array}$ & (99) \\
\hline
\end{tabular}




\section{Physiological disorders}

Different types of physiological disorders were reported in avocado fruit after 2 to 4 weeks' cold storage. ${ }^{(154)}$ The major disorders were vascular browning and grey pulp. ${ }^{(155)}$ When the fruit was exposed to less than 3 to $5{ }^{\circ} \mathrm{C}$ for more than two weeks they developed vascular browning and grey pulp. Vascular browning was described by Florissen et al. ${ }^{(156)}$ as mesocarp discoloration with a hardening of the vascular strands and an off-flavor development. A chilling injury (internal) symptom can be expressed as a greyish brown discoloration in the mesocarp especially at the basal end of the fruit around the seed and this is referred to as typical vascular browning that is initiated at the base of the fruit. The grey and dark discoloration in the mesocarp is reported as being grey pulp. ${ }^{(157)}$ 'Pinkerton' is the most susceptible cultivar to grey pulp and both controlled atmosphere storage and modified atmosphere packaging delayed, but did not prevent its development. ${ }^{(158)}$ Kruger et $a l .{ }^{(159)}$ mentioned that avocado fruit grown from different areas differed in their susceptibility to mesocarp discoloration. Season, irrigation regimes ${ }^{(160)}$ as well as calcium nutrition $^{(161)}$ also contribute to the observed differences in mesocarp discoloration. Pulp spot, also known as low temperature disorder, is another significant physiological disorder of avocados that can develop during storage. High incidences of pulp spot were commonly observed in the cultivar 'Fuerte' as small dark spots in the mesocarp and a blackening of the vascular bundles. This disorder was reported to be higher in early season than later season fruit. $^{(162)}$

During the browning process in the above mentioned physiological disorders, enzymatic oxidation of phenolic compounds to melanin, which is mediated by poly phenol oxidase (PPO), is responsible for the brown discoloration of the mesocarp. ${ }^{(123,128)}$ The activity of PPO was noted to increase due to ethylene production during the ripening of avocados. ${ }^{(155,163)}$ PPO activity takes 
place in presence of oxygen. Post-harvest moisture stress was reported to play a role in the initiation of physiological disorders therefore reducing the water loss by applying modified atmosphere packing may reduce flesh discoloration (browning). ${ }^{(164)}$ Bower and Cutting ${ }^{(165)}$ reported with increase of $\mathrm{ABA}$ content during initial stage of ripening and softening increased the PPO activity and residual ABA was negatively correlated with PPO activity. Comparative study on PPO activities in three avocado cultivars, 'Fuerte', 'Horeshim' and 'Lerman' indicated that the 'Fuerte' showed the highest activity where as Horeshim' and 'Lerman' showed lower PPO activities at matured stage. ${ }^{(166)}$ Moreover the initial PPO activity increased Quintal, Fortuna, cultivars than the 'Choquete'. Reports showed that the PPO activity was affected by cultivation practices and postharvest storage conditions. Peroxidase (POD) activity was shown to decrease with fruit maturation and according to Vanini et $a l .{ }^{(167)}$ in 'Quintal', 'Fortuna' and POD activity was related to the ripening process influencing the change in the fruit flavor, therefore, treatment capable of reducing POD activity will help during processing. In 'Fuerte' fruits and it POD activity declined with ripening and fruit softening and Zauberman et al. ${ }^{(168)}$ suggested that the POD activity in 'Fuerte' avocado fruit mesocarp has no role in the development of chilling injury or mesorcarp browning 


\section{Atmosphere modification and fruit quality}

\section{Controlled atmosphere}

Controlled atmosphere storage (CA) can be defined as a system where the desirable gas composition of reduced $\mathrm{O}_{2}$ and/ or increased $\mathrm{CO}_{2}$ can be regulated and maintained constantly throughout the storage and/ or transportation period. ${ }^{(169)} \mathrm{CA}$ storage is mostly used for long term storage of fruits such as apples but it is also being increasingly used in transportation of fruit by sea. Generally, $\mathrm{CO}_{2}$ delays many responses of fruit to ethylene. The higher $\mathrm{CO}_{2}$ and lower $\mathrm{O}_{2}$ in CA storage was reported to reduce the rates of respiration and ethylene production. ${ }^{(170)}$ Due to this phenomenon, CA can affect the postharvest physiology of the fresh produce depending on the $\mathrm{O}_{2} / \mathrm{CO}_{2}$ balance. Fabion et al. ${ }^{(171)}$ reported that the severity of chilling injury (physiological disorder) in avocados is reduced in low $\mathrm{O}_{2} /$ elevated $\mathrm{CO}_{2}$ atmospheres. However, $\mathrm{CO}_{2}$ levels exceeding 5\% may have a detrimental effect on 'Hass' avocado fruit quality and therefore specific optimum levels of $\mathrm{CO}_{2}$ in low $\mathrm{O}_{2}$ needs to be defined. Fruit maturity was shown to also have an influence on the severity of chilling injury in CA. 
Postharvest disease control can also be achieved by controlling host resistance through storing or shipping the fruit in CA conditions. ${ }^{(152)}$ The cultivars Fuchs and Waldin stored at $2 \% \mathrm{O}_{2}$ and $10 \%$ $\mathrm{CO}_{2}$ at $7.2{ }^{\circ} \mathrm{C}$ for 3 to 4 weeks had reduced anthracnose disease development after fruit softening or ripening at $21.1{ }^{\circ} \mathrm{C} .{ }^{(103)}$ The use of CA storage in disease control was more aimed at spore germination than controlling the radial mycelial growth of the fungus, but the main objective was to delay fruit softening so that the pathogen (C. gloeosporioides) would remain dormant. ${ }^{(103)} \mathrm{On}$ the other hand, a higher incidence of anthracnose was reported in 'Fuerte' stored at $1 \% \mathrm{O}_{2}$ and $10 \% \mathrm{CO}_{2}$, which was explained by the low $\mathrm{O}_{2}$ shock experienced by the fruit tissues resulting in the damaged cells becoming more susceptible to the anthracnose pathogen during ripening at 25 ${ }^{\circ} \mathrm{C} .{ }^{(161,172)}$ Generally, $\mathrm{O}_{2}$ content of $2 \%$ to $5 \%$ and $\mathrm{CO}_{2}$ of $3 \%$ to $10 \%$ are used to store avocados for five to six weeks. ${ }^{(162,173)}$ According to Burdon and Lallu ${ }^{(153)}$, CA storage can be maintained by adopting static (SCA) or dynamic (DCA) systems. DCA was defined by Toivonen and DeEll ${ }^{(174)}$ as where the gas mixture in the CA store will constantly change due to metabolic activity of the respiring fruits in the store. Where the $\mathrm{O}_{2}$ level falls below a threshold level several metabolic processes will change, which includes ethanol synthesis, and the chloroplasts will be stressed causing them to fluoresce. DCA uses the measurement of either chlorophyll fluorescence or ethanol production to control the $\mathrm{O}_{2}$ level in the store. In the SCA system, the $\mathrm{O}_{2}$ concentration is maintained at a pre-determined concentration until the end of the storage time. Burdon and Lallu ${ }^{(153)}$ indicate that DCA stored 'Hass' avocados grown in New Zealand ripened after four days, similar to the fruit that were stored and ripened in air, while the SCA stored fruit took seven days to ripen. DCA-stored avocados ripened more uniformly and had less fungal decay and physiological disorders. DCA was recommended in order to extend the storage time, while maintaining the overall quality of avocado for New Zealand avocado growers and 


\section{Table 8}

Controlled atmosphere storage of avocados ${ }^{\mathrm{a}}$

\begin{tabular}{llll}
\hline $\mathbf{C A}$ & $\begin{array}{l}\text { Temperature } \\
\text { regime }\end{array}$ & $\begin{array}{l}\text { Carbon dioxide/oxygen } \\
\text { concentration }\end{array}$ & Source \\
\hline 1 & $12^{\circ} \mathrm{C}$ & 3 to $10 \% \mathrm{CO}_{2}+2-5 \% \mathrm{O}_{2}$ & $(169)$ \\
2 & 10 to $13^{\circ} \mathrm{C}$ & 3 to $10 \% \mathrm{CO}_{2}+2-5 \% \mathrm{O}_{2}$ & $(170)$ \\
3 & $5^{\circ} \mathrm{C}$ & $5 \% \mathrm{CO}_{2}+5 \% \mathrm{O}_{2}$ & $(171)$ \\
4 & 2 or $5^{\circ} \mathrm{C}$ & $15 \% \mathrm{CO}_{2}+2 \% \mathrm{O}_{2}$ & $(93)$ \\
5 & $10^{\circ} \mathrm{C}$ & 3 to $5 \% \mathrm{CO}_{2}+3-5 \% \mathrm{O}_{2}$ & $(152)$ \\
6 & $10^{\circ} \mathrm{C}$ & $9 \% \mathrm{CO}_{2}+1 \% \mathrm{O}_{2}$ & $(152)$ \\
7 & $5^{\circ} \mathrm{C}$ & $9 \% \mathrm{CO}_{2}+2 \% \mathrm{O}_{2}$ & $(172)$ \\
8 & $6^{\circ} \mathrm{C}$ & $5 \% \mathrm{CO}_{2}+2 \% \mathrm{O}_{2}$ & $(153)$ \\
9 & $6^{\circ} \mathrm{C}$ & $5 \% \mathrm{CO}_{2}+2 \% \mathrm{O}_{2}$ & $(153)$ \\
10 & $6^{\circ} \mathrm{C}$ & $5 \% \mathrm{CO}_{2}+5 \% \mathrm{O}_{2}$ & $(174)$ \\
11 & $6^{\circ} \mathrm{C}$ & $10 \% \mathrm{CO}_{2}+2 \% \mathrm{O}_{2}$ & $(175)$ \\
12 & $5^{\circ} \mathrm{C}$ & $8 \% \mathrm{CO}_{2}+3 \% \mathrm{O}_{2}$ & \\
13 & $5.5^{\circ} \mathrm{C}$ & $10 \% \mathrm{CO}_{2}+2 \% \mathrm{O}_{2}(4$ weeks $)$ & \\
\hline
\end{tabular}

${ }^{\text {a }}$ Source: Thompson ${ }^{(90)}$ 
exporters. As with temperature recommendations, so controlled atmosphere storage recommendations vary and Thompson ${ }^{(49)}$ reviewed the recommendations for controlled atmosphere storage of avocados (Table 8).

\section{Modified atmosphere packaging}

In modified atmosphere (MA) packaging, the atmospheric composition (mainly moisture $\mathrm{O}_{2}$ and $\mathrm{CO}_{2}$ ) around the fruit is modified or altered by storing the fruit in plastic films sometimes with microperforations or the addition of chemicals inside the bags to control ethylene, $\mathrm{CO}_{2}$ and water vapor. In MA, the levels of $\mathrm{O}_{2}$ and $\mathrm{CO}_{2}$ cannot be controlled or regulated like in $\mathrm{CA}$. Different atmospheres are achieved by flushing the atmosphere with a predetermined $\mathrm{O}_{2}$ and $\mathrm{CO}_{2}$ at the beginning of storage. It can also be modified during storage by varying the film type and its gas permeability as well as the weight or volume of the fruit or vegetables and the storage temperature. ${ }^{(176)}$ When the internal atmosphere is modified by the respiration of a commodity, some gas equilibrium concentration will be reached in a few days time. At the equilibrium steady-state, it is assumed that the quantity of gas exchanged through the fruit skin is equivalent to that exchanged through the film. An equilibrium steady state is reached when the gas composition inside the package has stabilized. ${ }^{(176,177)}$

The use of MA packaging to market avocados is practiced in many countries and it is reported to delay ripening and prolong storage. Aharoni et $a l .{ }^{(177)}$ reported that decay was not reported as a major problem, since the fruit was properly sorted, incidences of decay in avocados packed in polyethylene bags. Storage life was extended by 3 to 8 days at various temperatures by sealing individual fruit in polyethylene film bags compared to those stored without packaging. ${ }^{(101)}$ 'Fuerte' fruit sealed individually in $25 \mu \mathrm{m}$ thick polyethylene film bags for 23 days at 14 to $17^{\circ} \mathrm{C}$ 
ripened normally on subsequent removal to higher temperatures. ${ }^{(178)}$ Levels of gases inside the bags after 23 days storage were $8 \% \mathrm{CO}_{2}$ and $5 \% \mathrm{O}_{2}$. Thompson et al. ${ }^{(100)}$ showed that sealing various seedling varieties of West Indian avocados in polyethylene film bags greatly reduced fruit softening during storage at various temperatures. Meir et al. ${ }^{(179)}$ recommended $5{ }^{\circ} \mathrm{C}$ in 30 $\mu \mathrm{m}$ thick polyethylene film bags for 'Hass', Scott and Chaplin ${ }^{(180)}$ recommended 4 to $7.5^{\circ} \mathrm{C}$ in $50 \mu \mathrm{m}$ polyethylene bags for 'Fuerte'. Eksteen and Truter $^{(172)}$ found that 'Fuerte' packed in polyethylene bags in cartons and stored at $5.5^{\circ} \mathrm{C}$ for 33 days and ripened at $20{ }^{\circ} \mathrm{C}$ atmosphere prolong their storage life but failed to control the incidence of anthracnose. A similar observation was reported by Oudit and Scott ${ }^{(181)}$ for the cultivar Hass. They explained that the higher humidity within the bags during ripening at $20{ }^{\circ} \mathrm{C}$ could have been the reason for the high incidence of anthracnose. MA packaging with an ethylene scavenger was also reported to reduce mesocarp discoloration and decay in avocados. ${ }^{(163)}$ Modified atmosphere packaging has many advantages, such as its easy implementation at the commercial level, biodegradable films can be used and therefore its application becomes more environmentally friendly. ${ }^{(182)}$ For avocados, the MA packaging technology provides many advantages including delaying the climacteric rise in respiration rate, thereby retarding ripening and deterioration processes. MA packaging can also prevent fruit browning by preventing loss of membrane integrity and prevents loss of electrolyte leakage by reducing the polyphenol oxidase activity. ${ }^{(183)}$ At the same time, MA packaging has been shown to inhibit the expression of hydrolytic enzymes involved in fruit softening in avocado and as a result it slows softening. ${ }^{(184)}$ The high humidity surrounding the fruit during MA packaging helps to reduce the weight loss during the marketing of the fruit. 


\section{Hypobaric storage}

Hypobaric storage is the storage under pressures of less than one atmosphere $(760 \mathrm{~mm} \mathrm{Hg}=$ $101.32 \mathrm{kPa}$ ) and has been used in storage and transport of fruit and vegetables. Burg ${ }^{(185)}$ summarised his work over many years on the effects of hypobaric storage on avocados. The cultivar Choquette stored at $14.4{ }^{\circ} \mathrm{C}$ under atmospheric pressure started to ripen in 8 to 9 days and they were fully ripe in 14 days. Softening of those under 5.3 to $13.3 \mathrm{kPa}$ began after 25 days and when transferred to $20^{\circ} \mathrm{C}$ under atmospheric pressure all fruit developed normal taste with no internal blackening or decay. Burg ${ }^{(185)}$ subsequently found that in storage at $12.8{ }^{\circ} \mathrm{C}$ hypobaric conditions at 13.3 to $20 \mathrm{kPa}$ was better than at 5.3 to $10.7 \mathrm{kPa}$ and in later work he reported that $2.7 \mathrm{kPa}$ was optimal at $10{ }^{\circ} \mathrm{C}$. With the cultivar Waldin, Burg ${ }^{(185)}$ reported that in storage at $10{ }^{\circ} \mathrm{C}$ their postharvest life was improved as the pressure was lowered from 13.3 to 20 $\mathrm{kPa}$ down to 8 to $10.7 \mathrm{kPa}$ with the fruit remaining firm for 30 days at to 8 to $10.7 \mathrm{kPa}$ compared to 12 to $16 \mathrm{kPa}$ at atmospheric pressure. Similar results were found in storage at $12{ }^{\circ} \mathrm{C}$ but all fruit ripened quicker. Spalding and Reeder ${ }^{(103)}$ compared storage of Waldin at $7.2{ }^{\circ} \mathrm{C}$ and 98 to $100 \% \mathrm{RH}$ for 25 days at atmospheric pressure in air with controlled atmosphere storage under $2 \% \mathrm{O}_{2}$ and $10 \% \mathrm{CO}_{2}$ or $2 \% \mathrm{O}_{2}$ and $0 \% \mathrm{CO}_{2}$ and two hypobaric storage conditions in $91 \mathrm{~mm} \mathrm{Hg}$, one with added $\mathrm{CO}_{2}$ at $10 \%$. After storage, all the fruit was ripened at $21.1{ }^{\circ} \mathrm{C}$. They found that $92 \%$ of the fruit stored in the controlled atmosphere of $2 \% \mathrm{O}_{2}$ and $10 \% \mathrm{CO}_{2}$ were acceptable and all those in the hypobaric conditions of $91 \mathrm{~mm} \mathrm{Hg}$ plus $10 \% \mathrm{CO}_{2}$, while none of the fruit in the other treatments were acceptable. The factors that affected acceptability were anthracnose disease and chilling injury, both of which were completely absent in fruit stored under $91 \mathrm{~mm}$ $\mathrm{Hg}$ plus $10 \% \mathrm{CO}_{2}$. They defined acceptable fruit as having good appearance, free of moderate or severe decay and chilling injury, and with no off-flavors. They also found no stem end rot 
(Diplodia natalensis) directly after storage but after ripening at $21.1{ }^{\circ} \mathrm{C}$. No stem end rot was detected except low levels on those that had been stored under $91 \mathrm{~mm} \mathrm{Hg}$ and higher levels were observed in the fruit that had been stored under $2 \% \mathrm{O}_{2}$ and $10 \% \mathrm{CO}_{2}$. Black pitted areas developed in lenticels during softening of avocados stored at atmospheric pressure or hypobaric plus $10 \% \mathrm{CO}_{2}{ }^{(186)}$. However, pitting was slight and was not considered to be objectionable to the average consumer. Tissue from the infected areas contained Pestalotia spp. fungus. From this they concluded that high $\mathrm{CO}_{2}$ was necessary for the successful storage of avocados since the hypobaric system would have reduced the partial pressure of $\mathrm{O}_{2} 91 \mathrm{~mm} \mathrm{Hg}$ would be about $2.5 \%$.

\section{Edible coatings}

The use of edible coatings or films in preserving fruit quality has of recent attracted the attention of many researchers in the food industry. Edible coatings are made from biopolymers such as carbohydrates, proteins and lipids however are biodegradable and are most importantly they are biodegradable. Edible coatings also act as surface barrier hindering the movement of gases thus creating an internal modified atmosphere in the fruit. However, different edible coatings made from different materials have different properties. Maftoon Azad ${ }^{(187)}$ found that the application of methyl cellulose a polysaccharide resulted in lower respiration, reduction in color changes in both skin and flesh as well as softening of the tissue and increased the shelf life in 'Hass' avocado with a maximum storage period of 10 days (1.5 times the control treatment) at room temperature. Similarly, the application of gelatine-starch coatings delayed the ripening process which resulted in firmer fruit and lower weight loss in 'Hass'. ${ }^{(188)}$ In addition a delay in respiratory climacteric pattern by 3 days was noticed in coated fruits stored at $20^{\circ} \mathrm{C}$. 


\section{Conclusions}

The critical stage in the life cycle of fruit is during postharvest because after harvest fruit quality can only be maintained and not improved. Avocado production in countries like South Africa, Israel and Chile is export-driven with the European Union being the biggest market and this entails high fruit quality standards. Consequently, stringent quality assurance systems and well managed postharvest management practices are required. The maintenance of fruit quality therefore begins from the point of harvest until it reaches the retailer or the table of the overseas consumer. During transportation, fruit is not only stored for long periods but handled at different transit points. As a result, avocado fruit quality can be lost due to fruit softening that occurs during ripening, the development of physiological disorders and decay development as a result of microorganism infection. Temperature management is one of the critical issues that need to be managed during this period because it is related to several physiological and biochemical processes of the fruit which ultimately affects fruit quality. Most avocado cultivars that enter international trade can be stored between 5 to $7{ }^{\circ} \mathrm{C}$ and care should be taken to avoid the development of physiological disorders especially chilling injury. MA, CA and hypobaric storage can be used in combination with low temperature to delay fruit ripening and reduce decay development. However, these technologies are expensive due to the equipment that is required. Application of 1-MCP to delay fruit ripening seemed to be promising in delaying ripening but the biggest challenge is the development of decay associated with the use of this compound. ${ }^{(189) \text {. }}$

Decay development mostly due to anthracnose and stem-end is another challenge faced during the supply chain. The use of fungicides such as prochloraz has been one of the traditional methods used to address the issue of postharvest decay development. However, there is a need 
for safer methods to control postharvest decay development due to an increase in consumer concern regarding food safety and demand for organically produced fruit. The use of bio-control agents, application of essential oils or plant extracts in combination with modified atmosphere packaging or edible coatings and heat treatment could be possible alternatives to fungicide use. The major limitations are that heat treatment might damage the tissue of the fruit and affect the marketability of the fruit, while on the other hand the use of essential oils and plant extract could have some impact on the sensory properties of the fruit. However, use of essential oils in lower concentration in vapor phase application can minimize the impact on sensory properties of the fruit. Combination of a bio-control agent with lower concentrations of fungicides or GRAS (Generally Regarded As Safe) compounds also reduces the postharvest losses due to postharvest diseases during the supply chain. All the new alternative treatments must be evaluated on different cultivars, at different maturity stages and according to fruit sizes or weights and at different seasons or locations at least over three seasons before they should be adopted commercially. Therefore, to have fruit of good quality either on the shelf of the retailer or on the table of the consumer an effectively managed supply chain is required and a range of technologies are required.

\section{Acknowledgements}

This work was supported by a grant from the Post-Harvest Innovation Programme (Fresh Produce Exporter Forum, South Africa and Department of Science and Technology). Authors express their thanks to Dr. Zelda van Rooyan, Westfalia Technological Services, Limpopo province, South Africa for providing valuable suggestions. 


\section{References}

1. Morton J.K. Fruits of warm climates. Miami, Florida, USA. 1987. http://www.hort.purdue.edu/newcrop/morton/emblic.html (accessed October 2012).

2. Bregh, B.O.; Ellstrand, N. Taxonomy of the avocado. California Avocado Society Yearbook 1986, $70,135-145$.

3. Chen, H.; Morrell, P.L.; Ashworth V.E.T.M.; de la Cruz, M; Clegg, M.T. Tracing the geographic origins of major avocado cultivars. Journal of Heredity 2009, 100, 56-65.

4. Whiley, A.W.; Schaffer, B.; Wolstenholme, B.N. The avocado botany, production and uses. CABI Publishing, New York, 2002, 416.

5. Zentmyer, G.A. Part IV. Avocado. In Compendium of tropical fruit diseases, APS Press, St Paul, Minnesota, 1994, 71-84.

6. Market research analyst. Avocado market forecast 2008-2012. 2008. http://www.indiaprwire.com/pressrelease/agriculture/200801166705.pdf (accessed December 2013)

7. Hernandez, G. Production and Trade Forecast to Grow GAIN report, 2011.

8. Food and agriculture organization (FAO). World agriculture: towards 2015/2030. An FAO perspective. Jelle Bruinsma,Ed.; Earthscan, London, and FAO, Rome 2003.

9. Eurostat. http://epp.eurostat.ec.europa.eu/portal/page/portal/agriculture/data/database, 2008.

10. De Bon, H. Fruitrop. No. 183, CIRAD. France, 2010.

11. USAID-TAPP. Market Bulletin. 2011. http://www.tanzania -agric.org | www.fintrac.com | Issue \#02 | (accessed 1 June 2011). 
12. Food and agriculture organization (FAO). United Nations. The state of food security in the world: addressing food insecurity in protracted crisis. Rome, 2010.

13. Schaffer, B.; Wolstenholme, B.N.; Whiley, A.W. The avocado botany, production and uses. CABI Publishing, New York. 2013.

14. Platt-Aloia, K. A.; Thomson, W.W. Ultrastructure of the mesocarp of mature avocado fruit and changes associated with ripening. Annual Botany 1981, 48, 451-465.

15. Slater, G.G.; Shankman, S.; Shepherd, J.S.; Alfin-Slater, R.B. Seasonal variation in the composition of California avocados. Journal of the Agricultural Food Chemistry 1975, 23, 468474.

16. Lu, Q.Y.; Arteaga, J.R.; Zhang, Q.; Huerta, S.; Go, V.L.; Heber, D. Inhibition of prostate cancer cell growth by an avocado extract: Role of lipid-soluble bioactive substances. Journal of Nutritional Biochemistry 2005, 16, 23-30.

17. Lee, J.; Koo, N.; Min, D. Reactive oxygen species, aging, and antioxidative nutraceuticals. Comprehensive Reviews in Food Science and Food Safety 2004, 3, 21-33.

18. FAO. United Nations. Agriculture, trade and food security: issues and options in the WTO negotiations on agriculture from the perspective of developing countries. Vol. I and II. Rome, 2000.

19. Lu, Q.; Zhang, Y.; Wang, Y.; Wang, D.; Lee, R.; Gao, K. California "Hass" avocado: profiling of carotenoids, tocopherol, fatty acid, and fat content during maturation and from different growing areas. Journal of Agricultural and Food Chemistry 2009, 57, 408-413.

20. Ozdemir, F.; Topuz, A. Changes in dry matter, oil content and fatty acids composition of avocados during harvesting time and post-harvesting ripening period. Food Chemistry. 2004, 86, 79-83. 
21. Torres, A.M.; Mau-Lastovicka, T.; Rezaaiyan, R. Total phenolics and high-performance liquid chromatography of phenolic acids of avocado. Journal of Agricultural and Food Chemistry. 1987, 35, 921-925.

22. Golukeu, M.; Ozdemir,F. Changes in phenolic composition of avocado cultivars during harvesting time. Chemistry of Natural Compounds. 2010, 46, 112-115.

23. El-Mageed, M.A.A. Development of volatile compounds of avocado and casimiroa during fruit maturation. Arab Univ. J. Agric. Sci. 2007, 15, 89-99.

24. Pereira, M.E.C. Changes in volatile compounds during ripening of West Indian-type 'Simmonds' avocado treated with ethylene and aqueous 1- methylcyclopropene. Proc. American Society for Horticultural Science Annual Meeting, 2010. 93.

25. Obenland, D; Collin, S.; Sievert, J. Negm, F; Lu Arpaia, M. Influence of maturity and ripening on aroma volatiles and flavor in 'Hass' avocado. Postharvest Biol. Technol. 2012. 17, $41-50$.

26. Defilippi, B.G.; Manríquez, D.; Luengwilai, K.; González-Agüero, M.. In. Aroma volatiles: biosynthesis and mechanisms of modulation during fruit ripening, Eds: Jean-Claude, K.; Michel, D. Adv. Bot. Res. Academic Press, 2009. 1-37.

27. Seymour, G.B.; Tucker, G.A. Avocado. In: Biochemistry of fruit ripening 1993, 1, 53-81.

28. Pesis, E.; Fuchs, Y.; Zauberman, G. Cellulase and softening in avocado. Plant Physiology 1978, 61, 416-419.

29. Kathryn, A.; Platt-Aloia, W.; Thomson, W.; Roy, E.Y. Ultrastructural changes in the walls of ripening avocados: Transmission, scanning, and freeze fracture microscopy. Botanical Gazette 1980, $141,366-373$. 
30. Hoffman, N. E.; Yang, S.F. Changes of 1-aminocyclopropane-1-carboxylic acid content in ripening fruits in relation to their ethylene production rates. Journal of American Society and Horticultural Science 1980, 105, 492-495.

31. Erickson, L.; Takaake, Y. Effect of temperature on the ripening of Hass avocados. Californian Avocado Society Yearbook 1964, 48, 92-94.

32. Zauberman, G.; Schiffmann-Nadel, M.; Yanko, U. The response of avocado fruits to different storage temperatures. HortScience 1977, 12, 353-354.

33. Tucker, M.L.; Laties, G.G. Interrelationship of polysome prevalence, gene expression, and respiration during ripening of ethylene and/or cyanide treated avocado fruit. Plant Physiology, 1984, 74, 307-315.

34. Awad, M.; Young, R.E. Postharvest variation in cellulase, polygalacturonase, and pectinmethylesterase in avocado (Persea Americana Mill, cv Fuerte) fruits in relation to respiration and ethylene production. Plant Physiology 1979, 64, 306-308.

35. Board, M.; Colquhoun, A.; Newsholme, E.A. High Km glucose phosphorylating (glucokinase) activities in a range of tumor cell lines and inhibition of rates of tumor growth by the specific enzyme inhibitor mannoheptulose. Cancer Research 1995, 55, 3278-3285.

36. Ishizu, T.; Winarno, H.; Tsujino, E.; Morita, T.; Shibuya, H. Indonesian medicinal plants. XXIV.1) Stereochemical structure of perseitol K+ complex isolated from the leaves of Scurrula fusca (Loranthaceae). Chemical and Pharmaceutical Bulletin, 2002, 50, 489-492.

37. Bertling, I., Bower, J.P. Sugars as energy sources- are there a link to avocado quality. South African Avocado Growers' Association Yearbook 2005, 28, 24-27. 
38. Liu, X.; Robinson, P.W.; Madore, M.A.; Witney, G.W.; Arpaia, M.L. 'Hass' avocado carbohydrate fluctuations, II: Fruit growth and ripening. Journal of the American Society for Horticultural Science 1999, 124, 679-681.

39. Meyer, M.D.; Terry, L.A. Development of a rapid method for the sequential extraction and subsequent quantification of fatty acids and sugars from avocado mesocarp tissue. Journal of Agricultural and Food Chemistry 2008, 56:7439-7445

40. Landahl, S.; Meyer, M.D.; Terry, L.A. Spatial and temporal analysis of textural and biochemical changes of imported avocado cv. Hass during fruit ripening. Journal of Agricultural and Food Chemistry 2009, 57, 7039-7047.

41. Blakey R.J.; Bower, J.P.; Bertling, I. Influence of water and ABA supply on the ripening pattern of avocado (Persea americana Mill.) fruit and the prediction of water content using Near Infrared Spectroscopy. Postharvest Biology and Technology 2009, 53, 72-76.

42. Pearson, D. Seasonal English market variation in the composition of South African and Israeli avocados. Journal of Science and Food Agriculture 1975, 26, 207-213.

43. Lee, S.K.; Young, R.E. Growth measurement as an indication of avocado fruit maturity. Journal of American Society of Horticultural Science 1983, 108, 395-397.

44. Knight, R.J. History, distribution and uses. In: the avocado: botany, production and uses, Whiley, A.W., Schaffer, B., Wolstenholme B.N., Eds.; Cabi Publishing, 1, 10.

45. Woolf, A.B.; Wexler, A.; Prusky, D.; Kobiler, E.; Lurie, S. Direct sunlight influences postharvest temperature responses and ripening five avocado cultivars. Journal of the American Society for Horticultural Science 2000, 125, 370-376.

46. Botha, B.M. Supercritical fluid extraction of avocado. South African Growers' Association Yearbook 1987, 27, 24-27. 
47. Swarts, D. H. A practical method of determining the oil content of avocados for growers Citrus and subtropical fruit. Journal of Horticultural. Abstract 1976, 511, 1977-3000.

48. Kruger, F.J.; Claassens, N.J.F.; Kritzinger, M.; Claassens, V.E. A short review of recent research on the impact of climatic conditions on the postharvest quality of South African export avocados. Revista Chapingo Serie Horticultura 1999, 5, 339-345.

49. Thompson, A.K. Postharvest technology of fruit and vegetable. Blackwell science, 1996, $170-281$.

50. Snijder, B.; Mathumbu, J.M.; Kruger, F.J. Development of fruit maturity and mineral content norms for export avocado cultivars from different South African avocado growing regions proceedings v world avocado congress. Actas V Congreso Mundial Del Aguacate, 2003, $641-645$.

51. Kassim, A.; Workneh, T.S.; Bezuidenhout, C.N. A review on postharvest handling of avocado fruit. African Journal of Agriculture Research. 2013, 8, 2385-2402.

52. Wedding, C.; Wright, S.; Grauf, R.D.; White, B.; Gadek, T.P. Effects of seasonal variability on FT-NIR prediction of dry matter content for whole Hass avocado fruit Postharvest Biology and Technology 2013, 75, 9-16.

53. Lee, S.K.; Young, R.E.; Schiffman, P.M.; Coggins, C.W. Maturity studies of avocado fruit based on picking dates and dry weight. Journal of American Society of Horticultural Science. 1983, 108, 390-394.

54. Woolf, A.B.; Requejo-Tapia, C.; Cox, K.A.; Jackman, R.C. 1-MCP reduces physiological storage disorders of 'Hass' avocados. Postharvest Biology and Technology 2005, 35, 43-60. 
55. Hofman, P.J.; Jobin-Decor, M.; Giles, J. Percentage of dry matter and oil content are not reliable indicators of fruit maturity or quality in late-harvested 'Hass' avocado. HortScience 2000, 35, 694-695.

56. Werman, M.J.; Neeman, I. Avocado oil production and chemical characteristics. Journal of American Oil Chemists Society 1987, 64, 229-232.

57. Ranney, C.A.; Gillette, G.; Brydon, S.; Mcintyre, A.; Rivers, O.; Vasquez, C.A. Physiological maturity and percent dry matter of California avocado. In Proceedings of 2 nd World Avocado Congress, 1992, 379-385.

58. Arpaia, M.L.; Van Rooyen, Z.; Bower, J.P.; Hofman, P.J.; Woolf, A.B. Grower practices will influence postharvest fruit quality. $2^{\text {nd }}$ Seminario International De Paltos. 2004, 1-9.

59. Köhne, J.S.; Kremer-Köhne, S. Picking Hass avocados without pedicel. South African Avocado Growers' Association Yearbook 1995, 18, 66.

60. Darvas, J.M. Eitology and control of some fruit diseases of avocado (Persea americana) at Westfalia estate. DSc thesis, University of Pretoria, Pretoria, 1982.

61. Duvenhage, J.A. The influence of wet picking on post-harvest diseases and disorders of avocado fruit. South African Avocado Growers Association Yearbook 1993, 16, 77-79.

62. Vuthapanich, S.; Hofman, P.; Klieber, A.; Whiley, T. Improving the marketability of Hass avocado through manipulation of production practices. Talking Avocados 1995, 6, 26.

63. PH Bulletin No. 18. Avocado (Pear): Postharvest Care and Market Preparation. January 2004.

64. Ultee, A.; Kets, E.P.W.; Smid, E.J. Mechanisms of action of carvacrol on the food-borne pathogen Bacillus cereus. Applied Environmental Microbiology 1999, 65, 4606-4610. 
65. Food and agriculture organization. Agriculture, trade and food security: Issues and options in the WTO negotiations on agriculture from the perspective of developing countries. 2005.

66. Ben-Yehoshua, S. Individual seal-packaging of fruit and vegetables in plastic film-A new postharvest technique. Horticulturae Science 1985, 20, 32-37.

67. White, A.; Woolf, A.B.; Hofman, P. Avocado care assessment manual, 2001, 66.

68. Darvas, J.M. The control of postharvest avocado diseases with prochloraz. South African Avocado Growers' Association Yearbook 1984, 7, 57-58.

69. Everett, K.R.; Owen, S.G.; Cutting, J.G.M. Testing efficacy of fungicides against postharvest pathogens of avocado (Persea americana Cv. Hass). New Zealand Plant Protection 2005, 58, 89-95.

70. Scheepers, S.; Jooste, A.; Alemu, Z.G. Quantifying the impact of phytosanitry standards with specific reference to MRLS on the trade flow of South African avocados to the European Union. Agrekon 2007, 46, 260-273.

71. Smith, L.A.; Dann, E.K.; Leonardi, J.; Dean, J.R.; Cooke, A.W. Exploring non-traditional products for management of postharvest anthracnose and stem end rot in avocado, in VI the World Avocado Congress. 2011. http://www.worldavocadocongress2011.com/?PageID=15 (accessed 22, October 2011).

72. Everett, K.R.; Korsten, L. Postharvest rots of avocados: improved chemical control by using different application methods. In Proceedings of the $49^{\text {th }}$ New Zealand Plant Protection Conference, 1996, 3, 37-40.

73. Mavuso Z.S.; Van Niekerk J.M. Development of a more effective post-harvest treatment for the control of post-harvest diseases of avocado fruit. South African Avocado Growers' Association Yearbook 2010, 33, 53-55. 
74. Lunt, R.E.; Smith, H.; Darvas, M.M. A comparison between waxing and cellophane wrapping of avocados for export. South African Avocado Growers' Association Yearbook 1981, $4,57-62$.

75. Johnston, J.W.; Banks, N.H. Selection of a surface coating and optimization of its concentration for use on 'Hass' avocado (Persea Americana) fruit. Crop and Horticultural Science. 1998, 26, 143-151.

76. Cutting, J.G.M.; Bower, J.P.; Wolstenholme, B.N. Effect of abscisic acid on abscisic acid metabolism, PPO activity, phenolics and quality in ripening avocado (Persea americana Mill.) fruit. South African Avocado Growers' Association Yearbook 1989, 12, 53-55.

77. Durand, B.J.; Orcan, L.; Yanko, U.; Zauberman, G.; Fuchs, Y. Effects of waxing on moisture loss and ripening of 'Fuerte' avocado fruit. Scientia Horticulturae 1984, 19, 421-422.

78. Kremer-Kohne, S.; Duvenhage, J.A. Alternatives to polyethylene wax as post-harvest treatment for avocados. South African Avocado Growers' Association Yearbook 1997, 20, 97 98.

79. Lemmer, D.; Kruger, F.J.; Malumane, T.R.; Nxudu, K.Y. 1-Methyl cyclopropene (1-MCP): An alternative for controlled atmosphere storage of South African export avocados. South African Avocado Growers' Association Yearbook 2002, 25, 25-34.

80. Vorster, L.L. The avocado industry in South Africa. California Avocado Society Yearbook 2005, 87, 59-62.

81. Elmsly, T.A.; Mandemaker, A.J.; Smith, D.B.; Dixon, J. Effect of the fruit coating Biocoat ${ }^{\mathrm{TM}}$ on ripe rots of 'Hass' avocados. New Zealand Avocado Growers' Association Annual Research Report. 7, 103-106. 
82. Kruger, F. Observation on relevant research: Wax on avocados and mangoes. Subtrop Quarterly Journal. 2013, 2, 22-26.

83. de Boer, A., 2010. Unapproved Food Additives Discovered in Wax on Apples. Report Food. Standards Agency

84. Itai A.; Tanahashi T. Inhibition of sucrose loss during cold storage in Japanese pear (Pyrus pyrifolia Nakai) by 1-MCP. Postharvest Biology and Technology 2008, 48, 355-363.

85. Zhang, Z.; Huber, D.J.; Rao, J. Ripening delay of mid-climacteric avocado fruit in response to elevated doses of 1-methylcyclopropene and hypoxia-mediated reduction in internal ethylene concentration. Postharvest Biology and Technology 2011, 60, 83-91.

86. Zhang, Z.; Huber, D.J.; Rao J. Antioxidant systems of ripening avocado (Persea americana Mill.) fruit following treatment at the preclimacteric stage with aqueous 1-methylcyclopropene. Postharvest Biology and Technology 2013, 76, 58-64.

87. Jeong, J.; Huber, D.J.; Sargent, S.A. 1-Methylcyclopropene and waxing regulate the ripening storage life of avocado fruit. HortScience 2000, 35, 468-469.

88. Perishable Product Export Control Board (PPECB). South African fruit export data. Information and Business Intelligence Division. Panorama. RSA, 2009.

89. Department of Agriculture Forest and Fisheries. A Profile of the South African Avocado Market Value Chain. Directorate Marketing, Arcadia. 2011. South Africa. http://www.daff.gov.za/docs/AMCP/AvocadoMVCP2010-11.pdf.(accessed June 17, 2012).

90. Thompson A.K. Controlled atmosphere storage of fruits and vegetables. Second edition. CAB International, Oxford, UK, 2010.

91. Anonymous. Recommended conditions for cold storage of perishable produce. International Institute of Refrigeration, Paris Basic Publication, 1967. 
92. Kader, A.A. Modified atmospheres. An indexed reference list with emphasis on horticultural commodities, supplement No. 4. Postharvest Horticulture Series 3, University of Califonia, Davis, 1985.

93. Snowdon, A. A colour atlas of post-harvest disease and disorders of fruits and vegetables, Vol. 1. Fruits and General Introduction. Wolfe Scientific, London, 1991.

94. Yahia, E.M. Persea americana Mill. In Postharvest biology and technology of tropical and subtropical fruits. Woodhead Publishing, Oxford, Cambridge, Philadelphia, New Delhi, 2001, 2, 125-185.

95. Lutz J.M.; Hardenburg R.E. The commercial storage of fruits, vegetables and florist and nursery stocks. United States Department of Agriculture, Agriculture Handbook 66, 1968.

96. Saucedo Veloz, C., Aceves Vega, E. and Mena Nevarez, G. Prolongacion del tiempo de frigoconservacion y comercializacion de frutos de aguacate 'Hass' mediante tratamientos con altas concentraciones de $\mathrm{CO}_{2}$. Proceedings of the Interamerican Society for Tropical Horticulture III Symposium on management, quality and postharvest physiology of fruits 1991, 35, 297-303.

97. Salunkhe D.K.; Desai B.B. Postharvest biotechnology of fruits. CRC Press, Boca Raton, 1984, 2, 387-396.

98. Eaks, I. L. Effects of chilling on respiration and ethylene production of 'Hass' avocado fruit at $20{ }^{\circ} \mathrm{C}$. Horticultural Science 1983, 18, 235-237.

99. Pantastico, E.B. Postharvest physiology, handling and utilization of tropical and sub-tropical fruits and vegetables. AVI Publishing Co., Westpoint, Conn., USA, 1975.

100. Thompson, A.K.; Mason, G.F.; Halkon, W.S. Storage of West Indian seedling avocado fruits. Journal of Horticultural Science 1971, 46, 83-88. 
101. Scott, K.J.; Chaplin, G.R. 1978. Reduction of chilling injury in avocados stored in sealed polyethylene bags. Tropical Agriculture 1978, 55, 87-90.

102. Corrales Garcia, J. Physiological and biochemical responses of "Hass" avocado fruits to cold storage in controlled atmospheres. $7^{\text {th }}$ international controlled atmosphere research conference. Proceedings volume 3: Fruits other than apples and pears, Davis, California. Postharvest Horticulture Series 1997, 17, 69-74.

103. Spalding, D.H.; Reeder, W.F. Low-oxygen, high carbon dioxide controlled atmosphere storage for the control of anthracnose and chilling injury of avocados. Phytopathology 1975, 65, $458-460$.

104. Marcellin, P.; Chevez, A. Effect of intermittent high $\mathrm{CO}_{2}$ treatment on storage life of avocado fruit in relation to respiration and ethylene production. Acta Hort 1983, 138, 155-163.

105. Lee, S.K.; Young, R.E. Temperature sensitivity of avocado fruit in relation to $\mathrm{C}_{2} \mathrm{H}_{4}$ teatment. Journal of the American Horticultural Science 1984, 109, 689-692.

106. Hofman, P.J.; Smith, L.G. Preharvest effects on postharvest quality of subtropical and tropical fruit. In Proceedings of International Conference on Postharvest Handling of fruit, Chiang Mai, Thailand, Champ, B.R., Highley, E., Johnson, G.I, Eds, 1993, 5, 261-268.

107. Meir, S.; Philosoph, H.S.; Lurie, S.; Droby, S.; Akerman, M.; Zauberman, G.; Shapiro, B.; Cohen, E.; Fuchs, Y. Reduction of chilling injury in stored avocado, grapefruit, and bell pepper by methyl jasmonate. Canadian Journal of Botany 1996, 74, 870-874.

108. Nishijima, K.A.; Chan, H.T.; Sanxter, S.S.; Linse, E.S. Reduced heat shock period of 'sharwil' avocado for cold tolerance in quarantine cold treatment. HortScience 1995, 30, 10521055. 
109. Florissen, P.; Ekman, J.S.; Blumenthal, C.; Mcglasson, W.B.; Conroy, J.; Holford, P.L. The effects of short heat treatments on the induction of chilling injury avocado fruit (Persea Americana Mill.). Postharvest Biology and Technology 1996, 8, 129-134.

110. Hofman, P.J.; Stubbings, B.A.; Adkins, M.F.; Meiburg, G.F.; Woolf, A.B. Hot water treatments improve 'Hass' avocado fruit quality after cold disinfestations. Postharvest Biology and Technology 2002, 24, 183-192.

111. Sabehat, A.; Weiss, D.; Lurie, S. The correlation between heat-shock protein accumulation and persistence and chilling tolerance in tomato fruit. Plant Physiology 1996, 110, 531-537.

112. Rozenzvieg, D.; Elmaci, C.; Samach, A.; Lurie, S.; Porat, R. Isolation of four heat shock protein cdnas from grapefruit peel tissue and characterization of their expression in response to heat and chilling temperature stresses. Plant Physiology 2004, 121, 421-428.

113. Polenta, G.A.; Calvete, J.J.; Gonzalez, C.B. Isolation and characterization of the main small heat shock protein induced in tomato pericarp by thermal treatment. Federation of European Biochemical Societies journal 2007, 274, 6447-6455.

114. Woolf, A.B.; Watkins, C.B.; Bowen, J.H.; Lay Yee, M.; Maindonald, J.H.; Ferguson. I. B. Reducing external chilling injury in stored 'Hass' avocadoes with dry heat treatments. Journal of the American Society for Horticultural Science 1995, 120, 1050-1056.

115. Ouma, G. Heat treatments affect postharvest quality of avocado. HortScience (Abstract), 2001, 3, 504 .

116. Vicente, A.R.; Costa, M.I.; Martinez, G.A.; Chaves, A.R.; Civello, P.M. Effect of heat treatments on cell wall degradation and softening in strawberry fruit. Postharvest Biology and Technology 2005, 38, 213-222. 
117. Smith, J. H. E.; Lunt, R. E. Storage temperature studies. South African Avocado Growers' Association Yearbook 1984, 7, 36-37.

118. Kritzinger, M.; Kruger, F.J. Preliminary results on the evaluation of hot water heat shock treatments of South African avocados. South African Avocado Growers Association Yearbook 1997, 20, 1-5.

119. Swarts, D.H. Die invloed van abnormale lae temperature op die ontwikkeling van koueskade by Fuerte avokado's. Subtropical 1980, 1, 16-18.

120. Dixon, J.; Smith, D.B.; Elmsly, T.A.; Pak, H.A. Quality of avocado (Persea americana Mill.) fruit after high humidity storage and/or exogenous ethylene removal. New Zealand Avocado Growers' Association Annual Research Report 2003, 3, 99-107.

121. Van Rooyen, Z.; Bower, J.P. Effects of storage temperature, harvest date and fruit origin on post-harvest physiology and the severity of mesocarp discolouration in 'Pinkerton' avocado (Persea americana Mill.). Journal of Horticultural Science and Biotechnology 2006, 81, 89-98.

122. Van Rooyen, Z. Semi-commercial trials to determine the risk of shipping 'Hass' at $1^{\circ} \mathrm{C}$ for 30 days. South African Avocado Growers' Association Yearbook 2009, 32, 36-41.

123. Perishable Product Export Control Board (PPECB). South African fruit export data. Information and Business Intelligence Division. Panorama. RSA, 2010.

124. Baile, J.B.; Young, R.E. The avocado. In The biochemistry of fruits and their poducts, Hulme, A.C., Ed., Academic Press, London, 1971.

125. Wills, R.B.H.; McGlasson, W.B.; Graham, D.; Lee, T.H.; Hall, E.G. Postharvest an introduction to the physiology and handling of fruit and vegetables. $3^{\text {rd }}$ ed.; BSP Professional Books, London, 1989. 
126. Hatton, TT.; Reeder, W.F.; Campbell, C.W. Ripening and storage of Florida avocados. Washington, D.C., Agricultural Research Service, U.S. Department of Agriculture 1965, 697.

127. Horpkirk, G; White, A.; Beever, D.J.; Forbes, S.K. Influence of postharvest temperatures and the rate of fruit ripening on internal postharvest rots and disorders of New Zealan 'Haas' avocado fruit. New Zealand Journal of Crop and Hortivultural Science 1994, 22, 305-311.

128. Bower, J.P.; Cutting, J.G.M. Avocado fruit development and ripening physiology. Horticulturae Reviews 1988, 10, 229-261.

129. Manicom, B.Q. Diseases. In The cultivation of avocado. Institute of Tropical and Subtropical Crops, Nelspruit, South Africa, 2001; pp 214-230.

130. Smilanick, J.L.; Margosan, D.A. Management of postharvest decay of avocado fruit. Califonia avocado research symposium 2001, 115-119.

131. Hartill W.F.T. Post-harvest diseases of avocado fruits in New Zealand. New Zealand Journal of Crop and Horticultural Science 1991, 19, 297-304.

132. Korsten, L. Biological control of avocado fruit diseases. Ph.D. thesis, University of Pretoria, 1993.133.

133. Bartlett, D.W.; Clough, J.M.; Godwin, J.R.; Hall, A.A.; Hamer, M.; Parr-Dobrzanski, B. The strobilurin fungicides. Pest Management Science 2004, 60, 309.

134. Willingham, S.L.; Pegg, K.G.; Coates, L.M.; Cooke, A.W.; Dean, J.R.; Langdon P.W.B.; Beasley, D.R. Field management of avocado postharvest diseases. Acta Horticulturae 2001, 553, $435-438$.

135. Ippolito, A.; Nigro, F. Impact of preharvest application of biological agents on postharvest diseases of fresh fruits and vegetables. Crop Protection 2000, 19, 715-723. 
136. Department of Agriculture Forest and Fisheries (DAFF). A Profile of the South African Avocado Market Value Chain. Directorate Marketing, Arcadia, South Africa. 2011. http://www.daff.gov.za/docs/AMCP/AvocadoMVCP2010-11.pdf. (accessed June 17, 2012).

137. Korsten, L.; DE Villiers, E.E.; Rowell, A.; Kotzé, J.M. Postharvest biological control of avocado fruit diseases. South African Avocado Growers' Association Yearbook 1993, 16, 65-69. 138. El Ghaouth, A.; Wilson, C. L.; Wisniewski, M.; Droby, S.; Smilanick, J. L.; Korsten, L. Biological control of postharvest diseases of citrus fruit. In Biological control of crop diseases, Gnanamanickam, S.S., Ed.; New York, Marcel Dekker, 2002, 289-312.

139. Janisiewicz, W.J.; Cornway, W.S. Combining biological control with physical and chemical treatments to control fruit decay after harvest. Stewart Postharvest Reviews 2010, 10, $1-3$.

140. Korsten, L.; Bezuidenhout, J.J.; Kotzé, J.M. Biocontrol of avocado postharvest diseases. South African Avocado Growers' Association Yearbook 1989, 12, 10-12.

141. Korsten, L.; De Villiers, E.E.; De Jager, E.S.; Cook, N.; Kotzé, J.M. Biological control of avocado postharvest diseases. South African Avocado Growers' Association Yearbook 1991, 14, $57-59$.

142. Regnier, T.; Combrinck, S.; du Plooy, W.; Botha, B. Evaluation of Lippia scaberrima essential oil and some pure terpenoid constituents as postharvest mycobiocides for avocado fruit. Postharvest Biology and Technology 2010, 57, 176-182.

143. Sellamuthu, P.S., Mafune, M., Sivakumar, D., Soundy P Thyme oil vapour and modified atmosphere packaging reduce anthracnose incidence and maintain fruit quality in avocado Journal of the Science Food and Agriculture 2013, 93, 3024-3031. 
144. Sellamuthu, P.S., Sivakumar, D., Soundy P. Korsten, L. Enhancing the defence related and antioxidant enzymes activities in avocado cultivars with essential oil vapours. Postharvest Biology and Technology 2013, 81, 66-72

145. Aveno, J.L.; Orden, M.E.M. Hot water treatment of mango: A study of four export corporations in the Philippines. 2012. http://www.Kmitl.Ac.Th/Ejkmitl/Vol4no1/Mangohwt.Pdf. (accessed August 23, 2012).

146. Kim, J.J.; Ben-Yehoshua, S.; Shapiro, B.; Henis, Y.; Carmeli, S. Accumulation of scoparone in heat-treated lemon fruit inoculated with Penicillium Digitatum Sacc. Plant Physiology 1991, 97, 880-885.

147. Rodov, V.; Burns, P.; Ben-Yehoshua, S.; Fluhr, R.; Ben-Shalom, N. Induced local disease resistance in citrus mesocarp (albedo): accumulation of phytoalexins and pr proteins. Proc. International Society for Citriculture 1996, 2, 1101-1104.

148. Pavoncello, D.; Lurie, S.; Droby, S.; Port, R.A. Hot water treatment induces resistance to Penicillium digitatum and promotes the accumulation of heat shock and pathogenesis-related proteins in grapefruit flavedo. Plant Physiology 2001, 111, 17-22.

149. Port, R.; McCollum, T.G.; Vinokur, V.; Droby, S. Effects of various elicitors on the transcription of a $\beta-1,3$-endoglucanase gene in citrus fruit. Journal of Phytopathology 2001, $150,1-6$.

150. Plumbley, R. A.; Prusky, D.; Kobiler, I. The effect of hot-water treatment on the levels of antifungal diene and quiescence of Colletotrichum gloeosporioides in avocado fruits. Plant Pathology 1993, 42, 116-120. 
151. Karunaratne, A. M.; Adikaram, N.K.B. Significance of time lapse between harvest and postharvest hot water treatment on a locally popular avocado variety. In Sri Lanka ACIAR proceedings. Disease Resistance in Fruit 1998, 80, 146-164.

152. Arauz, L. Mango anthracnose: economic impact and current options for integrated management. Plant Diseases 2000, 84, 600-611.

153. Burdon J.; Lallu N.; Haynes G.; McDermott K.; Billing D. The effect of delays in establishment of a static or dynamic controlled atmosphere on the quality of 'Hass' avocado fruit. Postharvest Biology and Technology 2008, 49, 61-68.

154. Zentmyer, G.A. Avocado diseases. Tropical Pest Management 1984, 30, 388-400.

155. Eaks, I.L. Ripening, chilling injury, and respiratory response of 'Hass' and 'Fuerte' avocado fruits at $20{ }^{\circ} \mathrm{C}$ following chilling. Journal of the American Society for Horticultural Science 1976, 101, 538-540.

156. Florissen, P.; Ekman, J.S.; Blumenthal, C.; McGlasson, W.B.; Conroy, J.; Holford, P.L. The effects of short heat treatments on the induction of chilling injury avocado fruit (Persea Americana Mill.). Postharvest Biology and Technology 1996, 8, 129-134.

157. Chaplin, G.R.; Wills, R.B.H., Graham, D. Objective measurement of chilling injury in the mesocarp of stored avocados. HortScience 1982, 17, 238-239.

158. Kruger, F.J.; Truter, A.B. Relationship between preharvest quality determining factors and controlled atmosphere storage in South African export avocados. Acta Horticulturae, 2003, 600, $109-113$.

159. Kruger, F.J.; Kritzinger, M.; Malumane, R. Recommendations for controlling the post harvest problems of the Pinkerton cultivar. South African Avocado Growers' Association Yearbook 2000, 23, 8-14. 
160. Bower, J. P. Effect of fruit water stress and irrigation regime in the ripening of stored avocado fruit, cultivar Fuerte. South African Avocado Growers' Association Yearbook 1984, 7, $55-56$.

161. Bangerth, F. Calcium related physiological disorders of plant. Journal of plant growth regulation $1979,17,97-122$

162. Swarts, D. H. Post harvest problems of avocados - let's talk the same language. South African Avocado Growers' Association Yearbook 1984, 7, 15-19.

163. Pesis, E.; Ackerman, M.; Ben-Arie, R.; Feygenberg, O.; Feng, X.; Apelbaum, A.; Goren, R.; Prusky, D. Ethylene involvement in chilling injury symptoms of avocado during cold storage. Post-harvest Biology and Technology 2002, 24, 71-181.

164. Bower, J.P.; Bertling, I. Shelf life extension and reduction of chilling injury of 'Hass' avocados stored at ultra-low temperatures. In Proceedings XXVII IHC-International Symposium on the Role of Postharvest Technology in the Globalisation of Horticulture, Seoul, Korea, 2008, 768, 189-194.

165. Bower, J.P.; Cutting, J.G.M. Some factors affecting post-harvest quality in avocado fruit. South African Growers' Association Year Book 1987, 10, 143-146.

166. Khan, V. Polyphenol oxidase activity and browning of three avocado varieties. Journal of the Science and Agriculture 2006, 26, 1319-1324.

167. Vanini, L.S.; Kwiatkowski, A.; Clement, E. Polyphenoloxidase and peroxidase in avocado pulp (Persea Americana Mill.) Ciência e Tecnologia de Alimentos 2010, 30, 525-531.

168. Zauberman, G.; Fochs, Y.; Akerman, M. Peroxidase activity in avocado fruit stored at chilling temperatures. Scientia Horticulturae 1985, 26, 261-265. 
169. Beaudry, R.; Luckanatinvong, V.; Solomon, T. Maintaining quality with CA and MAP. Acta Horticulturae 2006, 712, 245-252.

170. Kader, A.A. Biochemical and physiological basis for effects of controlled and modified atmospheres on fruits and vegetables. Food Technology 1986, 40, 99-100.

171. Fabion, D.F.; Mitchel, F.G; Meyer, G. Response of 'Hass' avocado to postharvest storage in controlled atmosphere. Proceedings of the $2^{\text {nd }}$ World Avocado Congress 1992, 467-472.

172. Eksteen, G.J.; Truter, A.B. Effects of controlled and modified atmosphere storage on quality of eating ripe avocados. South African Avocado Growers' Association Yearbook 1985, 8, 7880.

173. Kader, A.A. Avocado. In CA Requirements and Recommendations 2001, Postharvest Technology Research and Information Centre, University Of California, Davis, USA. Postharvest Horticulture 2001, 22, 29-70

174. Toivonen P.M.A.; DeEll J.R. Chlorophyll fluorescence, fermentation product accumulation, and quality of stored broccoli in modified atmosphere packages and subsequent air storage. Postharvest Biology and Technology. 2001, 23, 61-69.

175. Hardenberg, R.E. Effect of in-package environment on keeping quality of fruits and vegetables. Horticulturae Scientia 1971, 6, 198-201.

176. Zagory, D.; Kader, A.A. Modified Atmosphere packaging of fresh produce. Journal of Food Technology 1988, 42, 70-77.

177. Aharoni, Y.; Schiffman-Nadel, M.; Zauberman, G. Effects of gradually decreasing temperature and polyethylene wraps on the ripening and respiration of avocado fruits Israel. Journal of Agricultural Research 1968, 18, 77-82. 
178. Bishop, D. Controlled atmosphere storage. In: Cold and Chilled Storage Technology, Dellino, C.J.V. (ed.), Blackie and Sons Limited, London and Glasgow, UK, 1996.

179. Meir, S.; Naiman, D.; Akerman, M.; Hyman, J.Y.; Zauberman, G.; Fuchs, Y. Prolonged storage of 'Hass' avocado fruit using modified atmosphere packaging. Postharvest Biology and Technology 1997, 12, 51-60.

180. Scott K.J.; and Chaplin G.R. Reduction of chilling injury in avocados stored in sealed polyethylene bags. Tropical Agriculture 1978, 55, 87-90.

181. Oudit, D. D.; Scott, K. J. Storage of "Hass" avocados in polyethylene bags. Tropical Agrekon 1973, 50, 241-243.

182. Flores, F.B.; Martínez-Madrid, M.C.; Amor, M.B.; Pech, J.C.; Latché, A.; Romojaro, F. Modified atmosphere packaging confers additional chilling tolerance on ethylene inhibited cantaloupe Charentais melon fruit. European Food Research and Technology 2004, 219, 431435.

183. Kader, A.A. Modified and controlled atmosphere storage of tropical fruits. In Postharvest Handling of Tropical Fruits, ACIAR Conference Proceedings. Champ, B.R., Highley, E. and Johnson, G.I. (Eds.). Chang Mai, Thailand 1994, 50, $239-249$.

184. Kanellis, A.K.; Solomos, T.; Mattoo, A.K. Hydrolytic enzyme activities and protein pattern of avocado fruit ripened in air and in low oxygen, with and without ethylene. Plant Physiology 1989, 90, 257-266.

185. Burg, S.P. Postharvest physiology and hypobaric storage of fresh produce. CAB International, Wallingford, Oxford, UK, 2004. 
186. Spalding, D.H.; Reeder, F. Low pressure (hypobaric) storage of avocados. HortScience 1976, 11, 491-492.

187. Maftoon Azad, N. Evaluation of edible films and coatings for extending the postharvest shelf life of avocado.PhD thesis. McGill University. 2006.

188. Aguilar-Méndez, M.A.; Matín-Martínez, E.S.; Tomás, S.A.; Cruz-Orea, A.; Jaime-Fonseca, M.R. Gelatine-starch films: Physicochemical properties and their application in extending the post-harvest shelf-life of avocado (Persea americana). Journal of Science of Food and Agriculture 2008, 88, 185-193.

189. Hofman, P.J.; Jobin-Decor, M.; Meiburg, G.F.; Macnish, A.J.; Joyce, D.C. Ripening and quality responses of avocado, custard apple, mango and papaya fruit to 1methylcyclopropene. Australian Journal of Experimental Agriculture 2001, 41, 567-572. 